The Trend of Foreign Direct Investment movement: Did Unintended Nation Brand of legal-families play an instrumental role?

\author{
Oi-Yan Kam \\ University of Leicester \\ Leicester LE1 7RH \\ Email: oyjk1@le.ac.uk
}

\author{
Chin-Bun Tse* \\ University of West London \\ London TW8 9GA \\ Email: chin-bun.tse@uwl.ac.uk
}

*Corresponding Author 


\title{
The Trend of Foreign Direct Investment movement: Did Unintended Nation Brand of legal-families play an instrumental role?
}

\begin{abstract}
Combining the suggestion from Fan (2006) that a nation can have a brand image without deliberating efforts of nation branding and the work from Klerman et. al. (2011) on Colonial History and effects on legal systems, we view that legal-systems could be an unintended nation brand that could instrumentally affect Foreign Direct Investment (FDI) activitives. We classify 193 countries according to their Colonial History or no-Colonial History into 5 legal-families. Applying Generalised Methods of Moments (GMM) on a set of panel data, our empirical evidence shows that legal-families play an instrumental role in explaining FDI activities. The paper opens up a new ground of research on 'unintended' nation brand of which the nation branding literature largely focus on designed-nation-brand, and on FDI area in which we introduce a new determinant in addition to the traditional determinants that have been reported in the FDI literature.
\end{abstract}

Keywords: Foreign Direct Investment, Unintended Nation Brand, Legal System

\section{INTRODUCTION}

Most literature on Nation Branding is on how a country or a place make some efforts to create a distinguished brand following a designed plan or strategies of the local government. The purpose of doing so is to make the places more attractive to businesses and tourists, and in turn contribute to the economic growth. The ways to create Nation or Place Brands are numerous. Some examples are: Switzerland creates a brand as an expert of science, research and education to attract investments from China (Schlege, Jacot \& Fetscherin, 2011); Humborg (2010) explores how countries can use Democracy as nation brand.

However, there are some Nation or Place Brands that could be created unintentionally and naturally simply throughout the course of the historical development of a country or a place. One obvious example is a nation's culture that has been developing throughout the history with multiple factors that are hard to pin point what they are - things were just evolved in their own ways. Brach (2010) discusses this type of nation brand with examples from Switzerland, Sweden, 
Nigeria, and Poland. Fan (2006) suggests that a nation can have a brand image without deliberating efforts of nation branding. This is an interesting and powerful insight - nation brand can be created naturally even though there was no effort to create one.

In this paper, we are particularly interested in how the Colonial History of some countries have created unintended brands through the heritage (good or bad) of legal systems. It is not the purpose or scope of this paper to make a judgement on the Colonial History. Instead, we argue that the Colonial History and the related Legal systems can form an unintended nation brand which in turn can play an instrumental role of attracting Foreign Direct Investments (FDI).

We use the data from 193 countries and apply System Generalised Methods of Moments (GMM) on a set of panel data. The findings support our hypothesis that Colonial History did form an unintended nation brand via legal systems and attracted FDI. .

Our findings fill a gap in the nation brand literature that largely focus on the intended brand. We present evidence that unintended nation brand can be powerful to attract investments. This could, hopeful, stimulate further research in the field of unintended nation brand. Moreover, this is a first study looking at the impact of legal families on FDI. Our findings show a fresh line of enquiry on FDI determinants that have been researched extensively for some time.

Whilst scholars agree that the concept of 'similar economic behaviours' is linked to countries of the 'same legal-family groups', Klerman et al. (2011) argue that La Porta et al (1997, 1998, 2008)'s work on legal origins could not truly explain economic development. They claim that legal origins and colonial history are strongly correlated. It would be more appropriate to attribute the economic growth to other aspects of colonial policy. They re-classify the legal origin countries into five groups, namely, (1) former English colonies, (2) former French colonies, (3) former colonies of French Civil law countries other than France (for example, Belgium, Italy, the Netherlands, Portugal, Spain, Ottoman Empire, and pre-communist Russia), (4) other former colonies and (5) countries never colonized. Their conceptual theory resides in the colonial history of the countries. This paper intends to follow the new legal systems classification based on colonial history to investigate further whether the trends of FDI activities could be better explained than the previous legal familiar classification.

As Kam (2011) shows that there are increasing proportions of global FDI from developed to developing economies. A logical question to ask is what are the factors that have motivated and 
influenced the recent trend of FDI movements? Specifically, we aim to provide answers to the following questions:

1. Does a country's legal family (unintended nation brand) matter for attracting FDI inflows to the developing countries?

2. Is applying the colonial powers theory proposed by Klerman et al. (2011) to classify legal families of countries providing a better explanation of the FDI movements than the previous classification?

The paper is organized as follows. The next section reviews the relevant literature and develops the theoretical framework of our study. Section 3 presents the classification of countries according to their legal family, colonial history, geographic and cultural factor. Section 4 presents the data and empirical methodology. Section 5 discusses findings and analyses the results. The final section 6 concludes the paper.

\section{LITERATURE AND THEORETICAL FRAMEWORK}

The effect of Nation Branding on FDI has been studied previously. For example, Kalamova \& Konrad (2010) report that one index point increase on the Anholt Nation Brand Index can correspond to $27 \%$ increase of FDI, that is substantial. One important point emerging from the literature is that almost all of them focus on the 'designed' Nation Branding to attract FDI. In this paper, however, we are particularly interested in the effect of an Unintended Nation Brand in attracting FDI. Fan (2006) suggests that a nation can have a brand image without deliberating efforts of nation branding. This is an interesting and powerful insight. In a similar vein, Jaffe and Nebenzahl (2001) emphasise nation branding must embrace political, cultural, business and sport activities. These mean that a nation could have an unintended nation brand simply because of its historical political and culture rather than specially create one. Amongst all potential unintended nation brands, Klerman et al. (2011) ground breaking paper on Colonial History and Legal Origin prompt us to think that Legal systems could be a Nation Brand although it is not created by design. We are interested in the legal systems derived by the colonial history or in some countries no colonial history at all, and whether it can explain the trends of FDI observed. 


\subsection{Divergence of policies: during the Colonial era and the Post-colonial period}

Engerman and Sokoloff (2002) argue that European colonizers adopted different institutional policies for their administration. They emphasize that the economic development of the colonial countries depends largely on which institutions- 'extractive' or 'protective'- the colonizers have established during the colonial era. During the colonial era, nearly all the colonizers established 'extractive' institutions in their ex-colonies from which they intended to exploit resources for their own interest. Such extractive institutional policies were commonly adopted elsewhere, with a few exceptions where protective institutions (favourable policies) were established in some selected colonies where the colonizers sought to settle down.

In the ex-colonies such as the countries in Latin America and the Caribbean, while the colonizers merely wanted to exercise their 'political powers' to exploit the benefits from their colonies, there is no incentive for them to educate the inhabitants as well as improving their basic infrastructure. Under the absolute political power of the colonists, most of the ex-colonies were unable to develop effectively because they did not provide a positive business environment (lack of skilled workers and modern infrastructure as well as deficiencies in legal enforcement) to attract foreign investment. Hence, these countries have had low development since the 19th century and thus fell behind economically.

In the post-colonial period, most of the former colonizers have shown an interest in providing aid and assistance to their ex-colonies. They have endeavoured to help the ex-colonies to protect human rights and fight against inequality, and to promote democratization and economic development as well as condemning racism and apartheid.

It is reasonable to assume that, once a country able to provide a good educational human workforce; improved infrastructure and an effective legal system with enforcement to protect the investors' intellectual property rights, this country will be able to attract foreign investment. Investors basically intend to find a place where they can produce their goods at lower production cost (cheap labour and land) and can maximise their sales in larger markets as well as accessing an abundant supply of resources, provided that their property assets and investments can be protected. Thus, when the governments of the ex-colonies can proceed with their institutional reform to satisfy these elements of location advantages, which previously they did not have, their economies will gradually grow. 


\subsection{Classification of Legal-families: English Common Law, French Civil Law}

The characteristics of legal culture have been basically defined as "ideas, values, expectations and attitudes towards law and legal institutions which some public or some part of public holds" ((Friedman 1977 in Nelken, 1977 (ed)). More explicitly, some authors refer to 'legal culture' as a part of the country's heritage synonymously with tradition (Ehrmann 1976). Conclusively, Merryman (1985:2) elaborates that a legal tradition is "deeply rooted in historically conditioned attitudes about the nature of law... the role of law in ...operation of a legal system...It puts the legal system into cultural perspective". Thus, a study of the legal system involves a number of legal traditions and sub-traditions providing an insight into the evolution of legal systems.

At the beginning of the 20th Century, researchers started conducting a wide range of comparative studies on the concept of 'families of law'. The study of comparative law was introduced aiming to underpin a unification of civilised legal systems. Glendon et al. (1992) point out that legal scholars agree that some national legal systems are sufficiently similar in certain critical respects and, therefore, could be classified into major families of law. However, there was no unanimity way on the 'correct' classification of legal families.

In the recent decades, economists omit the former socialist legal system from their analysis base. Since then many writers (such as Glaser and Shleifer, 2002 and La Porta et al. 2008) identify the countries as coming from two main traditions: Common law and Civil law in which they include French, German, and Scandinavian law as sub-traditions. As such, the laws of most countries are heavily influenced by either 'English Common Law' or 'French Civil Law'.

\subsection{Legal Origins Theory}

Over the last two decades, there has been a considerable body of research analysing the pervasive influence of a country's legal system in relation to legal rules and economic outcomes. La Porta et al. (1997, 1998) investigate the origins of each country's legal system, discussing its causal relationship with financial development and economic outcomes. They identify the countries as coming from two main traditions: English common law and French civil law in which La Porta et al. (1998) include German and Scandinavian law as sub-traditions. The legal system of common law countries originates from English law while the system of French, German and Scandinavian civil law countries originates from Roman law. 
La Porta's empirical works show that legal origins are highly correlated with the content of the law. Analyses were made by taking a set of key legal rules, primarily corporate and bankruptcy laws, into shareholder and creditor rights indices for each country. Furthermore, also some other measures of enforcement quality represented by 'the efficiency of the judicial system' and 'the quality of accounting standards' served as proxies for the stances of the law towards investor protection. The study examined the variation of legal rules and enforcement quality across 49 representative countries chosen from Europe, North and South America, Africa, Asia, and Australia. The sample consisted of 18 English common law origin countries, 21 French civil law origin countries, 6 German law origin countries, and 4 Scandinavian countries. Empirical results show that legal families appear to shape legal rules and, in turn, influence financial markets and economic outcomes (La Porta et al. 1998, and 2000). Shareholders and creditors have greater protection in common law countries than in civil law countries. More explicitly, "common law countries protect both shareholders and creditors the most, French civil law countries the least, and German civil law and Scandinavian civil law countries somewhere in the middle" (La Porta et al. 1997:1132). Results also show that there is a weaker protection of property rights and investment from minority investor in civil law countries than is the case with English common law countries.

\subsection{Theory of Legal 'Colonial Powers'}

Following the legal origins theory from LLSV and others, Klerman et al. (2011) reclassify the legal families in order to explain more fully the institutional qualities that might be transplanted from the colonizers. They argue that LLSV's work on legal origins could not truly explain economic growth. They argue that colonial policy matters, and they re-classify the legal origin countries into five groups.

The theory of 'Colonial powers' stresses that institutional quality and judiciary influence are being left as colonial legacies which contribute as dominating factors to a country's economic growth and development. This sounds reasonable because different institutional qualities would have become embedded in the specific cultural, political and economic conditions of the colonized countries, and that would have a substantial impact on their financial development and economic growth and thus on their FDI activities. The preceding discussion provides an explanation of the influential importance of legal qualities that have been transmitted to countries worldwide through occupation and colonization. Obviously, countries with legal qualities from 
colonizers of the same 'legal-family' group would be sufficiently similar in certain critical respects, and FDI flows differ to countries on the basis of different legal-family groups.

Conclusively, there has been a wide range of discussions relating FDI-growth to institutiongrowth. Nevertheless, we consider all three (FDI, institution, and growth) as essential elements of our study. Such arrangement would be able to assess the effect of institutional qualities (in particular under legal origins and colonial powers concern) on economic growth and FDI activities. To the best of our knowledge, this is the first empirical study which compares the influential importance of the pervasive legal origin theory originated from La Porta et al. (1997, 1998, 2008) and the 'colonial powers' theory from Klerman et al. (2011) broadly across 193 developed and developing countries. Our results support the claim that institutional quality is a likely determinant of FDI particularly for emerging countries such as the Caribbean. This may explain the recent trend of FDI movements.

\section{Classification of countries}

This paper intends to adopt a new classification method to investigate the recent trend of FDI activities. Since our paper aims to assess the trend of foreign direct investment under a 'legalfamilies' consideration, we must clearly focus on how legal families might be appropriately classified. Our approach is to compare the FDI growth rate among the countries in different legal family-groups; we also need to classify the countries in the world by regions. That is, the countries are categorised according to both their legal families and their geographic/cultural situation. This would allow us to locate those countries which have faster growth as regards FDI inflows.

\subsection{Classification of countries into different legal families}

For this study, it is necessary to identify as many as possible the countries' legal systems in terms of codification so that we can allocate them in the appropriate legal-family groups. We obtained the required data directly from Professor Daniel Klerman's database ${ }^{1}$, which was used in his paper Klerman et. al. (2011), that was originally sourced the colonial power coding from the Encyclopaedia Britannica Online.

\footnotetext{
${ }^{1}$ One of the authors contacted Professor Daniel Klerman asking if he could provide the coding from his database. Professor Klerman was so kind to provide not only the coding from himself but also the coding used by La Porta et al. (1997, 1998, and 2008).
} 
To verify the data, we also checked with other publications, such as Zweigert \& Kötz (1998), Roberts-Wray (1996), Campbell (2006), International Encyclopaedia of Comparative Law, Law \& Judicial Systems of Nations, Modern Legal Systems Cyclopaedia, and the World Legal Systems Website of the University of Ottawa ${ }^{2}$. Accordingly, we postulate a table with the coding of legal and colonial origins and thus putting 193 countries as well as several districts/cities ${ }^{3}$ in their corresponding legal families (see Table 1) and present it in the Appendix.

The families in terms of 'Legal origin' are listed in the horizontal rows while the families under 'colonial powers' are listed in the vertical columns, such that a clearer picture in comparing the coding for the countries in terms of legal origin and colonial powers is displayed ${ }^{4}$. This enables us to compare the explanatory power of these two classifying methods and estimate the relative importance of legal origin and colonial history.

\subsection{Regional classification}

In addition, classifying countries according to their legal families, we also group them in accordance with their geographic/cultural belonging. This would partly serve as a control purpose in our empirical tests and analysis so that we know whether the FDI trends were affected by legal families or simply the geographic/cultural belonging. It will also help us to observe and understand why some countries stand out from the group (an integrated group in terms of legal families and geographical/regional classification) and to forecast the future destination of FDI inflows.

As presented in Table 2, countries/districts ${ }^{5}$ are allocated in the different regions. The countries are categorised using criteria including (1) their physical geographic situation; (2) their human geographic ${ }^{6}$ involvement; (3) having sufficient countries in each of the regional groups so as to meet requirements for conducting the intended regression analysis. The arrangements adopted allow us to study the country-groups using a holistic approach. As a result, we can explore

\footnotetext{
${ }^{2}$ The World Legal System Research Group, JuriGlobe, of University of Ottawa provides a wide range of legal data on its website: http://www.juriglobe.ca/eng/ [Accessed on August 21, 2013].

${ }^{3}$ We also include several districts/cities which are the regional cities or special administrations but are economical prosperous (for example, Scotland, Louisiana, Taiwan and Hong Kong) in our table for analysis.

${ }^{4}$ Details of our 'legal families' classification are available on request, or perhaps refer to the to the thesis of Kam, Oi (2015): Chapter 5 from p.106 to p.129 under the Link: http://hdl.handle.net/2381/32525.

${ }^{5}$ There are 242 countries/districts classified into ten groups, in which 49 countries/districts are being opted out from our analytic base due to lack of available FDI data. Therefore, we have 193 countries/districts as our sample countries.

${ }^{6}$ The countries' human activities relating to population, economic activities, political and agricultural systems would also been taken into consideration. For example, we put nearly the entire African groups in a single entity called 'Sub-Saharan Africa' region.
} 
theFDI activities in the countries of different legal-family groups within each of the regions, which have been specifically defined to make our regression analysis possible and reliable ${ }^{7}$.

\section{DATA AND METHOdOLOGY}

\subsection{DATA}

Our data for the FDI variables are collected from World development indicators by the World Bank for the period of 1970-2014 for 193 countries. This panel dataset over 193 countries is time averaged in such a way to observe FDI measure ( $\left.F D I_{i t}\right)$ over nine '5-year sessions'. Specifically, the model is estimated over the periods from '1970-1974' to '2010-2014'8. As such, each of the variables defined in Table 3 represents the average values of the variables over the preceding five years. The only exception being the legal origin dummy (both Legal origins and colonial powers) which assumes a value of 1 if the legal system is civil code law and 0 otherwise.

We use a 5-year session period for analysis because we wish to gauge the forecasting horizon for the FDI measure as it is an unanticipated component extending about five years into the future. It means that when we lag once, the current series will have to start one session period after, i.e. at the '1975-1980' session and end at '2010-2014'. In addition, each unit of measure increases on the logarithmic scale, and, therefore, can cover a large range of scales.

We posit that once the leaders of the regimes are able to provide good education, modernised infrastructure and a good legal system with enforcement to protect the investors' property assets, other things being equal, these countries will be more able to attract foreign investment. Thus, we need the data to proxy legal-related institutions in addition to non-legal-related economic and financial measures.

To measure legal-related institutional quality parameters, our study based on the three dimensions of institutional quality, we fetch the data of 'Law and Order' (Rule of Law) and 'Corruption' to assess 'security of property rights' as one of the dimensions. In the face of such concerns, the rule of law (law and order) is the judiciary regulation that the government brings credibility to its commitments by delegating to court to secure the citizens' personal safety and property assets. The latter is an essential element to gain FDI inflows as foreign investors need

\footnotetext{
${ }^{7}$ Details of regional classification of the countries are available on request, or perhaps refer to the thesis of Kam, Oi (2015): Chapter 6 from p.134 to p.145 under the Link: http://hdl.handle.net/2381/32525.

8 The nine '5-year sessions' are: '1970-1974', 1975-1979', 1980-1984', 1985-1989', 1990-1994', ‘1995-1999', ‘20002004', '2005-2009' and '2010-2014'.
} 
the protection of their knowledge-based assets as one the first priorities. We follow La Porta et al. (1998) and Staats and Biglaiser (2012) and use the International Country Risk Guide (ICRG) provided by the PRS Group ${ }^{9}$ to assess the strength of law and impartiality of the legal system in the countries worldwide, as a proxy for the rule of Law. To assess the corruption in the global countries, the data of the 'Corruption Perception Index (CPI) of 2012 provided by 'the Transparency International Corruption: the global coalition against corruption' is used.

The second institutional dimension is measured by the data of 'Bureaucratic Quality' and 'Government Stability' sourced from the International Country Risk Guide (ICRG) provided by the PRS Group (2012).

As for the third-dimensional assessment, we use the new version Polity IV (2012) to assess the political issues of authoritarian-democracy situation of the states in the world system for comparative and quantitative analysis, but it is averaged over the five-year interval throughout the sample period.

The three dimensional institutional qualities are the contributing factors to tell if a country has a stable economic environment and potential laws to secure the investors' property assets. However, investors are concerned with the emergence of independent judges and impartial courts that could effectively apply the law in place for the protection of their knowledge-based assets, in particular. To account for legal enforcement, Staats and Biglaiser (2012) and Dogru (2012) use the 'Judicial Independence' dataset from the 'Economic Freedom of the World (EWF)' provided by the Fraser Institute as one of the independent variables for their empirical analyses. We follow them to obtain the data of 'Judicial Independence' as one of the instrumental variables. Since 'Judicial Independence' is regarded as enforcement of the law by independent judges at impartial courts, it is casually related to the institutional variables particularly 'Rule of Law'. Therefore, we treat it as an instrumental variable in our 'Generalised Method of Moments (GMM)' framework to account for the endogeneity problem ${ }^{10}$.

\footnotetext{
${ }^{9}$ We use the ICRG dataset (T3B data) of 2012 which was released in March 2013 for analysis.

${ }^{10}$ It is due to the correlation between 'judiciary independence' and the institutional independent variables in particular 'rule of law'. To this end, Beck et al. (2000) use the legal origin of each country as an instrumental variable to extract the exogenous component of financial intermediary development. This achieved to address the unobserved cross-country effect and the problem of endogeneity.
} 
We posit a framework to embrace both the theories of 'legal origins' and 'colonial powers' to explore their influential effect on the economic performance and FDI activities of the global countries. The data for Legal origins and colonial powers are obtained from Professor Daniel Klerman, who kindly sent us the coding from both his database and also from those of La Porta et al. (1997, 1998, and 2008). Accordingly, we produce a table with the coding of legal and colonial origins for putting 193 countries/districts in their corresponding legal families concerned. (See Table 1).

We also employ non-legal proxies for other institutional, economic and financial measures which address the manner of legal and colonial origins to the trend of FDI movements. Our main nonlegal variables are 'Human capital', 'Infrastructure', 'Trade openness', 'Wealth', 'M2/GDP' and 'Inflation rate' to capture the economic and financial impacts. These economic and financial data are obtained from the World Bank Statistics, except the data of Human Capital (proxied by the Average secondary schooling 15$)^{11}$ which are sourced from Barro and Lees (2012).

We also include 'Trade Openness' as one of the independent variables to explain FDI because when a country is open to trade and capital flows, it is more likely to develop its financial system. As such, 'trade openness' and 'financial openness' are, therefore, complementary to each other.

As well, we choose 'M2' as the independent variable to assess financial factors involved in FDI measurement. It is commonly used to assess financial development because it is a comparatively less liquid monetary aggregate - M2/GDP. Wealth is chosen to measure the sum of natural, human and physical assets; In addition, the 'inflation rate' is chosen to gauge the impact of nominal interest rate minus the real interest rate.

Conclusively, in order to explore the effect of legal origins on FDI activities, we will use 'Legal origins' (under Legal origins theory and Colonial powers theory) as the instrumental variables to account for the endogeneity problem, together with other instruments. These variables work as complementary instruments with the two legal-related variables that will produce consistent and efficient estimates to control the presence of the cross-country effect. Thus, a more reliable and convincing empirical result could be computed. The description of the variables is shown in Table 3 as in the appendix.

\footnotetext{
${ }^{11}$ Barro and Lee (2012) illustrate that the number of students at the age of 15 who could still receive secondary education would more accurately measure 'human capital' because students at 15 would have attained completed and near to completed secondary school education, thereby be able to provide the potential source of skilled workers.
} 


\subsection{Methodology}

\subsubsection{Model Specification}

While much of the previous literature has used cross-sectional analysis, we are using a panel data approach. By using a panel dataset, we can gain degrees of freedom by adding the variability of the time-series dimension, and more importantly, to control for the unobserved country specific effects. Moreover, a dynamic panel estimator can produce consistent and efficient estimates when the country-specific effects are correlated with the lagged independent variables.

The model takes the general form,

$$
\begin{aligned}
& Y_{i, t}=\beta_{1} Y_{i, t-1}+\beta_{2} X_{i, t}+\mu_{i, t} \\
& \mu_{i, t}=\eta_{i+} \varepsilon_{i, t}
\end{aligned}
$$

The extended form of (4.1):

$$
Y_{i, t}=B_{1} Y_{i, t-1}+\beta_{2} X_{i, t}+\eta_{i}+\varepsilon_{i, t}
$$

where the composite error is $\mu_{i, t}=\eta_{i}+\varepsilon_{i, t}$ and $i, t$ represent countries and time periods respectively. $\eta_{i}$ and $\varepsilon_{i, t}$ are the idiosyncratic disturbances $Y_{i, t}$ is the dependent variable and $X_{i, t}$ is the explanatory variables. Specifically, $Y_{i, t}$ is the logarithm of 'FDI measure' over a five year session period, $Y_{i, t-1}$ is the logarithm of 'FDI measure' at the start of that period, $X_{i, t}$ represents the explanatory variables other than lagged 'FDI measure', $\eta_{i}$ is the unobserved country-specific effect of country $i, \varepsilon_{i, t}$ are the observation-specific errors of country $i$ at time period $t$.

\subsubsection{Endogeneity problem}

The presence of a lagged dependent variable as explanatory variables in the equation (4.1) and (4.2) means that the Ordinary Least Squares (OLS) estimator will yield biased coefficient estimates. It is because there are possible correlations between with the variables of lag and other explanatory variables. Therefore, it violets the assumption of MLR3 which should be strictly complied with. To this end, Hsiao (1986) shows that OLS estimates of the autoregressive parameter will be an upward bias in the presence of individual-specific effects. To overcome this problem, the GMM estimation method will be used to address the biases due to unobserved cross - 
country effect, the presence of lagged dependent variables, and the problem of endogeneity. (Campos and Kinoshita, 2003).

\subsubsection{The Generalised Method of Moments}

The general GMM estimation principle is based on a set of population moment conditions, also called orthogonality conditions. A GMM estimator can then be obtained by solving the sample equivalent of these orthogonality conditions, to identify the parameters of interest. Let us now formalise this general estimation principle in a panel data framework, by using the general notation introduced in equation (4.1).

Let us rewrite equation (4.1) in the following way

$$
Y_{i, t}=\beta_{0}+\beta_{1} Y_{i, t-1}+\beta_{2} X_{1 i, t}+\beta_{3} X_{2 i, t}+\mu_{i, t}
$$

Where: $X_{1 i, i}$ represents the institutional variables such as Corruption, Rule of law, Bureaucratic Quality, Government Stability, and Polity IV; $X_{2 i, t}$ is a set of contemporaneous (and lagged) explanatory variables such as Infrastructure, Trade openness, Wealth, M2, and Inflation rate. Therefore, there are possible correlations between $\mu_{i, t}$ with the explanatory variables $Y_{i, t-1}$ (that is $F D I_{i . t-1}$ ) and $X_{1 i, i}$, resulting in biased coefficient estimates if OLS is used as an estimation technique.

Fundamentally, some of the regressors are endogenous so that $E\left(X_{1, t}^{\prime} \mu_{i, \mathrm{t}}\right) \neq 0$ (Institutions and lagged FDI). So, the $K_{1}$ regressors $X_{1}$ are potentially endogenous, and the remaining $\left(K-K_{1}\right)$ regressors $X_{2}$ are assumed to be exogenous. Also, $Z_{i}$ is $n \mathrm{x}$ $L$ vector, which is the full set of instrumental variables that are assumed to be exogenous, i.e. $E\left(Z_{i} \mu_{i}\right)=0$. We partition the instruments $\left[Z_{1} Z_{2}\right]$, where the $L_{1}$ instruments $Z_{1}$ are excluded instruments, and the remaining $\left(L-L_{1}\right)$ instruments $Z_{2} \equiv X_{2}$ are the included instruments as well as exogenous regressors.

The moment estimation principle rests on the assumption that the instruments, satisfy the conditional moment restrictions $\mathrm{E}\left[\mathrm{Z}_{i} \mu_{i, t}\right]=0$. The GMM estimator based on these moment conditions minimizes the following quadratic form, where the population moments have been replaced with their sample counterparts: 


$$
\operatorname{Min}_{\theta}\left[\frac{1}{N} \sum_{i=1}^{N} Z_{i} \mu_{i t}\right]^{\prime} W_{N}\left[\frac{1}{N} \sum_{i=1}^{N} Z_{i} \mu_{i t}\right]
$$

Where $\mu_{i t}=Y_{i t}-\beta_{0}-\beta_{1} \mu Y_{i t-1}-\beta_{2} X_{1 i t}-\beta_{3} X_{2 i t}$ and $W_{N}$ is a positive definite weighting matrix. A White type robust estimate of the weighting matrix allows to consider both heteroscedasticity and autocorrelation over time, see Cameron and Trivedi (2005:746). An efficient GMM estimator is obtained by replacing $W_{N}$ with $S^{-1}=\frac{1}{N} \sum_{i=1}^{N} Z_{i}^{\prime} \widehat{\mu_{l t}} \widehat{\mu}_{\imath t}^{\prime} Z_{i}$

\subsection{Testing the validity of instruments}

While the System GMM approach allows us to obtain consistent and efficient estimators, the validity of the instruments plays an important role to achieve these properties. Newey and Smith (2004) find that the general GMM estimator suffers from quite large finite sample biases. While the one-step GMM estimator uses weight matrices of independent estimated parameters, the efficient two-step GMM estimator weights the moment conditions by a consistent estimate of their covariance matrix and it would be best suited for System GMM estimation model (Windmieger, 2006).

After computing the GMM estimates, we would use the Hansen test to identify for over-identification to assess whether the instruments used are not correlated with the residuals under the null hypothesis. As discussed earlier, when the number of instruments $L$ is larger than the number of parameters $K$ the model is over-identified under the null of joint validity, the vector of empirical moments $\frac{1}{N} \mathbf{Z}^{\prime} \hat{\mathbf{E}}{ }^{12}$ is randomly distributed around zero. Noticeably, the Hansen test for over-identification is the way to make feasible by substituting a consistent estimate of the minimized value of a feasible GMM estimator. Conclusively, our System GMM estimation is to drive the vector of empirical moments $\frac{1}{N} \mathbf{Z}^{\prime} \hat{\mathbf{E}}$ close to zero, and then we test if it is close to zero.

${ }^{12} \hat{\mathbf{E}}$ is the estimate of the vector of residuals for individual $i$ 
Furthermore, we apply a Wald test ${ }^{13}$ to test for the joint null-hypothesis that the coefficient on all additional variables are zero. If it does, the statistics are the chi-squared value $\left(\chi^{2}\right)$ distributed with degrees of freedom. Based on the p-value, we are able to reject the null hypothesis, indicating that these variables create a statistically significant improvement in the fit of the

\section{Results and Analysis}

Table 4 presents the correlation matrix between foreign direct investment and legal influence and economic performance in our sampled countries, which are classified of different legal families according to the theory of 'legal origins' or 'colonial powers'. From this table, it shows a high correlation $(52 \%$ highlighted in bold and underlined) between 'French legal origin' and 'FDI inflows in Latin America and the Caribbean'. While looking at the French related legal-families under 'colonial powers' classification, there is as much as $86 \%$ correlation (highlighted in bold and underlined) between 'Spanish French origin' and 'FDI inflows in Latin America and the Caribbean', leaving the rest of the French legal entities relatively insignificant, particularly the 'Former French' which shows a negatively insignificant figure of $12 \%$ (highlighted in bold and underlined). This initial analysis indicates that in general 'colonial powers variable' would be capable of showing the real situation of FDI activities.

We present the GMM estimation for assessing the influential importance of legal qualities in different legal-family groups and studying the trend of FDI movements. We would like to undertake two parts of regression analysis. Firstly, we treat 'Legal Origins' and 'Colonial Powers' as independent variables. Each of them is put together with other independent variables such as the economic, finance, and institutions so that we can assess its effect as well as the joint significance of these instrumental variables on FDI activities in the global countries of different legal families and regions.

We name the first part of empirical analysis the 'Group A' and the second part the 'Group B'. We study four legal traditions (under Legal Origins theory) and twelve

\footnotetext{
${ }^{13}$ We follow 'the Institute for Digital Research and Education' which provides clear explanation on the application of Wald test in STATA. See http://www.ats.ucla.edu/stat/stata/fag/nested tests.htm
} 
selected legal-family groups (under Colonial Powers theory) in 10 regions $^{14}$ as to compare the levels of FDI movements in these family-groups under 'Legal Origins' and 'Colonial powers' classification.

In Group A, the first set of tables, Tables 5 and 6, the estimation results on the levels of FDI inflows to countries of various legal family-groups across 10 regions are presented. Table 5 shows the levels of FDI inflows in the countries mainly classified into four main family groups according to La Porta et al.'s (1997, 1998, and 2008) classifying method; they are British legal origins, French legal origins and the German legal origins as well as Scandinavian legal origins as sub-tradition. Table 6 presents the levels of FDI inflows to the countries classified in twelve legal familygroups according to Klerman et al. (2011)'s classifying method.

A similar pattern in terms of legal-family groups and regional classification can be recognised for another set of tables, Tables 7 and 8 . However, they assess the levels of FDI inflows as a percentage of real GDP according to the classification mode of 'Legal Origins theory' and 'Colonial Powers theory' respectively. This set of tables would show how important FDI would contribute to the countries' economies under legal quality concern and would act as a complement to explain the results of Tables 5 and 6.

We begin with a general assessment of the value of $F D I_{-1}$, in the first set of tables in Group A; both Tables 5 and 6 show positive results of $F D I_{-1}$ in nearly all legal-family groups at $1 \%$ significance level. These results indicate that past FDI values have a significant influence on current FDI activities. Similar significant results in most of the regions are seen in the second set of Table 7 and 8 ; the results indicate that foreign direct investment is important for the country's GDP growth. This would illustrate that a stronger FDI inflows will provide additional capital to boost the country's economy.

Coming back to the comparative study of the levels of FDI inflows, in Table 5, when legal families are classified into four main groups for analysis under La Porta et al.'s classification mode, it is noted that most of the estimation results are generally not

\footnotetext{
${ }^{14}$ One more legal family known as 'Latin America only with the Caribbean' is included in the Tables 5 and 7 in order to detect the FDI activities in the countries mainly in South America only.
} 
statistically significant; however, French Civil Law origins in Latin America and the Caribbean (presented in Column B2) is positive at the 5\% significance level [0.46**] inferring that there are substantial FDI inflows to the region. Under the term 'French Civil law origins', for the countries in Latin America and the Caribbean, it should generally refer to all those countries and territories in the Americas where Romance language is spoken. It, therefore, covers all the Spanish-, French-, and Portuguesespeaking countries in Latin America and the Caribbean ${ }^{15}$. As such, the results in Table 5 serve to present a wider view on FDI moving to all French-speaking countries in the region, which is, including the Spanish, French, Portuguese, and Dutch colonies.

In short, the findings are just singling out that those countries of 'French civil origins' in Latin America and the Caribbean are experiencing substantial FDI inflows. This would support that Latin America and the Caribbean have the greatest growth of FDI inflows at the remarkable increasing rate. The findings are in line with UNCTADWorld Investment Statistics (2009-2014) which reported that FDI activities have been increasingly and consistently flowing to developing countries particularly Latin America and the Caribbean.

Table 6 is designed to assess the levels of FDI inflows in countries classified into more legal-families according to Klerman et al. (2011)'s classification mode. In Table 6, clearly most of the regression results are generally not statistically significant with several exceptions. Similar to Table 5, in Table 6, positive and significant results are seen in the region of Latin America and the Caribbean no matter whether it is categorised to embrace all the countries of 'Spanish colony' [11.21** in column B (3)] at 5 percent level of significance or those 'Spanish colonies without the Caribbean involved [8.95*** in column B (9)] at 1 percent level of significance. Indeed, they show that FDI is specifically moving to the countries of 'Spanish colony' which is further classified from French civil law origins as it was in Table 5.

To explain further, in Table 5, the Roman speaking countries are categorised in a group of a single entity in the name of the French civil law origins; while, in Table

\footnotetext{
15 There are totally 50 countries in Latin America and the Caribbean listed in our compiled table 2; and there are 40 countries with available data for analysis. In which 16 of them are ex-colonies/colonies of Spain mainly in the South America continent; 9 of them are ex-colonies/colonies of Britain mainly in the Caribbean called British west indices. Other ex-colonies/colonies belong to France, Portuguese and the Brazilian Empire, Netherlands, and the U.S.
} 
6, the Roman speaking countries are further classified into more legal-family groups under 'colonial powers' concern. They are 'Former French', 'Spanish colony', 'Portuguese colony', and 'Dutch colony'. As such, the estimation results from Table 6 show evidence that FDI is merely significantly flowing to the countries of Spanish colony but not the whole French civil law countries under a single entity.

In Table 6, significant and positive results at 5\% level of significance are also seen in the regions of 'Eastern Asian and South-Eastern Asia' [10.12** in column C(12)] and 'Post-Soviet States' [15.49** in column F(12)]. By referring to Table 1 and Table 2, we can find out China is a country in the region of 'Eastern Asian and SouthEastern Asia' which is categorised in the legal group under 'Others'. It has been one of the destinations of foreign investment as it could protect the investors' property assets to a certain extent ${ }^{16}$. Similarly, in Table 1, we can find a list of countries that were the former Soviet Union. Most of these countries have been keen to adopt favourable institutions so that they can attract foreign investment. Besides, less positive and significant result [4.24** in column $\mathrm{G}(1)]$ at $5 \%$ confidence level is seen in North Atlantic Ocean, which is the region we postulate to include the developed countries on both sides across the Atlantic Ocean for regression analysis ${ }^{17}$. The result may indicate that the developed countries in this region (such as the United States) are still the hot destinations of FDI, but the level of inflows is on the reducing trend ${ }^{18}$ in comparison with the emerging countries, for example, in Latin America.

In Group B, Table 7 and 8 are the complementary set of tables we use to assess the levels of FDI inflows as a percentage of real GDP to further explain the impact of legal quality on FDI activities in relation to the countries' economies. In Table 7, the regression results are not statistically significant in the classified four legal families. A comparative study in Table 8 shows that there are negative and statistically significant results at $5 \%$ confidence level ${ }^{19}$ in assessing the level of FDI in relation

16 After the implementation of 'open door policy', in 1987, China established the general principles of civil law. There have been 130 laws approved by the National People's Congress (NPC).

17 Most of the countries in the Americas are grouped under 'Latin America and the Caribbean', leaving 5 countries -Bermuda, the US, Greenland and 'Saint Pierre and Miquelon' in the district. With only 5 countries, it is unable to provide sufficient observation for empirical tests. Therefore we combine them across the Atlantic with the countries in Northern Europe forming a cross-continental group.

18 Here the 'reducing trend' is measured in terms of percentage. That is, it is not quantified by measurement of the actual figures of inward FDI, but by comparison of the percentage of increase of FDI inflows among the countries in the preceding year.

19 Confidence level: $* * *$ and $*$ indicate that the coefficient is significantly different from zero at the $1 \%$, and $10 \%$ respectively. 
to real GDP growth in the regions of 'Eastern and South-east Asia' [-26.70** in column $\mathrm{C}(5)]$ and $[-6.17 * *$ in column $\mathrm{C}(1)]$. The results may suggest that FDI is dominant in these regions, but it contributes relatively less or in reducing rate to the real GDP growth of the economies.

As far as the countries of 'German never colonised' in 'Eastern and South-East Asia' $[-26.70 * *$ in column $\mathrm{C}(5)]$ are concerned, the countries of components in the region could be narrowed down to one country ${ }^{20}$, which is Japan. Reasonably, Japan is expected to follow the same track as it is in the U.S. and other developed countries that FDI provides relatively less in the proportion of GDP contribution.

The same is true for analysing the countries of 'former English' in 'Eastern and South-East Asia' [-6.17** in column C(1)]. The representing countries, by referring to Table 1 and Table 2, are Hong Kong, Singapore, and India. They are also on the same track, as it is in the United States, to become the sources of providing global FDI and provide relatively less in the proportion of GDP contribution. Perhaps they are now becoming the essential financial and re-entry ports such as Hong Kong and Singapore.

Table 8 also shows positive and significant results at $1 \%$ confidence level in the region of Latin America and the Caribbean [2.06*** in column $\mathrm{B}(3)]$, and $5 \%$ confidence level of significance in the regions of Latin America only [5.62** in column B(9)], Eastern Asia and South-Eastern Asia [19.12** in column C(12)] and Post-Soviet States ${ }^{21}[1.40 * *$ in column F(12)]. The results indicate that FDI has a substantial contribution to the GDP growth of economies in these regions. By referring to Table 1, we can find out those countries that enjoy GDP growth via FDI enhancement. Notably, they are China, the Russian Federation, and the Latin American countries.

Indeed, the regression results in both Group A and Group B suggest that 'Legal qualities', e.g., legal origins and judiciary independence, has a substantial impact on 'FDI measures' no matter whether it is classified under 'Legal Origins theory' or

\footnotetext{
20 Firstly we refer to Table 2 in the Appendix, from which we can find out a list of countries which belong to the classified region of 'Eastern and South-Eastern Asia'. Then we refer to Table 1 from which we can single out that Japan is the country we need to analyse.

21 In Table 1, we put some countries in Eastern Europe and Central Asia as one of the legal family group as they are mostly the Post-Soviet States.
} 
'Colonial Powers theory'. The findings suggest that 'Colonial powers' and 'Legal Origins' matters about FDI activities. The results also illustrate that legal families while classified into sub-divided groups under 'Colonial Powers theory' would more truly reflect the real situation of FDI activities. The findings also demonstrate that the legal-families grouping under colonial powers theory explains better the trend of FDI than under legal origin theory.

\section{Conclusion}

Our findings confirm that the current trend of FDI is moving to the countries that were economically behind such as Latin America and the Caribbean. This finding is in line with UNCTAD statistics (2009-2014) which reported that FDI activities have been consistently and increasingly flowing to developing countries, particularly in Latin America and the Caribbean. Indeed, nearly all the countries in Latin America and the Caribbean were colonies/ex-colonies.

The results are the outcome of regression on the data that proxy legal-related institutions and non-legal-related institutions such as Human Capital, Trade Openness, Wealth, M2/GDP, Infrastructure, etc., that are the necessary components of Band equity being translated into customer preference, loyalty, and financial gains. The strong results of FDI flowing to Latin America and the Caribbean underpin that the countries in this region have huge enhancement of country position in the global market place, reflecting their stronger position than before in providing favourable environment, such as the size of domestic market, access to regional trade areas, education of the population for more skilful workers, good infrastructure for better communication and transportation, and favourable business environment to protect the investors' property rights, signifying nation banding address the image and message to further a country's political, social and economic gains and create competitive advantage (Fan, 2005:10).

As such, while our regression results support that FDI has been continuously flowing to Latin America and the Caribbean signify that 'Brand differentiates products' identifying countries on the strengths of the size of the domestic market, access to regional trade areas, for which the divergence of policies during the Colonial era and the Post-colonial period matter because the poorer countries would develop faster under the Catch-up Theories of productivity. 
Based on this theory, "it is easier for a country to grow fast if it starts out relatively poor". Where workers experience a lack of capital (tools) for production, "small amounts of capital investment would substantially raise these workers' productivity. By contrast, workers in rich countries have large amounts of capital with which to work...[an] additional investment has a relatively small effect on productivity" (Mankiw, 2012: 541-542). So, poorer countries could have faster growth if they are able to attract foreign investment. That is what we call the catch-up effect. To this end, we would like to make a subsequent research on the influence of such effect on FDI activities.

Besides, our results support legal scholars claim that national legal systems are sufficiently similar in certain critical respects and, therefore, could be classified into major families of law. Our results support this argument as FDI is noted moving to some particular legal family groups. To this end, results from Tables 6 and 8 designed to further classify legal families into more groups, can reflect more truly the FDI moving trend. In fact, Latin America and the Caribbean are the regions where various colonialism is seen.

Our findings would also have illustrated the impacts of legal and colonial history on foreign investment movements. It supports the theory of 'Colonial powers' which stresses that institutional quality and judiciary influence are being left as colonial legacies that contribute as dominating factors to a country's economic growth and development. Reasonably, different institutional qualities would have become embedded in the specific cultural, political and economic conditions of the colonized countries, and that would have a substantial impact on their financial development and economic growth and thus on their FDI activities. It also underscores that effect of the 'unintended' Nation Branding due to Colonial History $(\mathrm{CH})$ and Legal Origin (LO) that can explain Foreign Direct Investment (FDI) in both developing and developed countries. 


\section{References:}

Brach, B. (2010), “Nation brand Issues of culture and institutionalization", Place Branding and Public Diplomacy, Vol.6(3), pp. 256-262.

Barro, R. J., and Less, J., (2012), “Data Set for a Panel of 138 countries”, Faculty of Business and Economics, the University of Melbourne.

Beck, et. al., (2000), "Finance and the sources of growth", Journal of Financial Economics 58 (2000) 261-300

Cameron, Colin A., and Trivedi, Pravin K., (2005), "Microeconometrics: Methods and Applications", Cambridge University Press, Cambridge, United Kingdom.

Campbell, Cristian (ed.), (2006), "Legal Aspects of Doing Business in the Middle East", Netherlands: Kluwer Law International.

Campos, Nauro F, and Kinoshita, Yuko, (2003), "Why Does FDI Go Where it Goes?", New Evidence from the Transition Economies", International Monetary Fund Working Paper, 2003, 228.

Djankov, Simeon, La Porta, Rafael, Lopez-de-Silanes, Florencio, Shleifer, Andrei, (2003), “Courts", Quarterly Journal of Economics 118, 453-517.

Dogru, B South Asia", MPRA Paper No. 40471.

Ehrmann, H, W., (1976), “Comparative Legal Cultures”, Prentice-Hall.

Engerman, S. L., and Sokoloff, K. L., (2002), “Factor Endowments, Inequality, and Paths of Development among New World Economics", Working Paper 9259, National Bureau of Economic Research: Cambridge.

Fan, Y. (2006), “Branding the Nation: What is being Branded?”, Journal of Vacation Marketing, Vol.12 (1), pp. 5-14.

Freidman, L., (1977), “The Concept of Legal Culture: A reply”, in Nelkan, D., (eds), “Comparing Legal Cultures (1977)”, Dartmouth.

Glaeser, E.L., and Shleifer, A., (2002), "Legal Origins", the President and Fellow of Harvard College and Massachusetts Institute of Technology, The Quarterly Journal of Economics, November 2002.

Glendon, Mary Ann, Michael Gordon and Christopher Osakwe, (1992), "Comparative Legal Traditions in a Nutshell”, St. Paul: West Publishing Company, 1992.

Hansen, H., and Rand, j., (2005), "On the Causal Links between FDI and Growth in Developing Countries”, UNU-WIDER Research Paper No. 2005/31, Helsinki

Hsiao, C., (1986), “Analysis of panel data”, Cambridge: Cambridge University Press. 
Humborg, C. (2010), "Democracy and nation brand(ing): Friends or foes", Place Branding and Public Diplomacy, Vol.6(3), pp.183-197.

"International Encyclopedia of Comparative Law", (2011), edited by Konrad Zweigert and U. Drobnig, Martirus Nijhoff Pubishers, May 2011.

Jaffie, Eugene, D, and Nebenzahl, Israel, D., (2001), "National Image and Competitive Advantage: The Theory and Practice of Country-of-Origin effect", Edition 1, Copenhagen Business School Press, ISBN: 87-16-13516-4.

Kalamova, M., and K. Konrad (2010), Nation Brands and Foreign Direct Investment, Kyklos International Review for Social Sciences, vol 63:3, pp. 400 - 431.

Kam, O, (2011), “The determinants of Foreign Direct Investment (FDI): A panel data study of developed and developing countries". 38th Annual Conference International Business: Hosted by: Academy of International Business: UK and Ireland Chapter, University of Edinburgh, UK.

Kam, O, (2015), “The Trend of Foreign Direct Investment under Legal-Families Consideration”, Thesis submitted for the degree of Doctor of Philosophy at University of Leicester.

Klerman, D., Mahoney, P., Spanmann, H., and Weinstein, M. I., (2011), "Legal Origin or Colonial History?", Journal of Legal Analysis Advance, Vol 3 (2), pp. 379 - 409.

Kolter, P., and Gertner, D., "Country as branded, productand beyond: A place marketing and band management perspective”, revised on 16 January 2002, Journal of Brand Management, April 2002, ABI/INFORM.

La Porta, R, Lopez-de-Silanes, F., Schliefer, A., and Vishny, R., (1997), "Legal Determinants of External Finance”, Journal of Finance, 52, pp 1131-1150

La Porta, R., Lopez-de-Silanes, F., Schliefer, A, and Vishny, R., (1998), “Law and Finance”, Journal of Political Economy, 106(6), 1113-1155

La Porta, R., Lopez-de-Silanes, F., Schliefer, A., and Vishny, R., (2000), “Investor Protection and Corporate Governance”, Journal of Financial Economics, Vol. 58, Issues 1-2, pp. 3-27.

La Porta, R., F. Lopez-de-Silanes, F., and Shleifer, A., (2008), “The Economic Consequences of Legal Origins”, Journal of Economic Literature, 46, 285-332

"Law and Judicial Systems of Nations", (2002), 4th edition, edited by the World Jurist Association, Washington.

Mahoney, Paul G., (2001), "The Common Law and Economic Growth: Hayek Might be Right", Journal of Legal Studies, Vol. 30, No. 2, PP. 503-525, June 2001.

Merryman, J (1985), “The Civil Law Tradition”, $2^{\text {nd }}$ edition, Standard University Press. 
“Modern Legal Systems Cyclopedia", (1984), edited by Williams, S. Hein and Co., Inc., 21 Vols. K530, M63, 1984.

Newey W.K., and Smith, R. J., (2004), "Higher order properties of GMM and generalized empirical likelihood estimators", Econometrica, 72, 219-255.

Roberts-Wray, Kenneth, (1996), "Commonwealth and Colonial Law", New York: Frederick A., Praeger.

Schlegel, F., Jacot, O. and Fetscherin, M. (2011), "Science diplomacy with swissnex China: A Swiss nation brand initiative", Place Branding and Public Diplomacy, Vol.7(4), pp.289298.

Shimp, T. A., Saeed, S., and Madden, T. J., (1993), “Countries and their products: A cognitive structure perspective”, Journal of the Academy of Marketing Science, Vol. 21, No. 4, pp.323-330.

Shimp, et.al., (2001), "The Country-Of-Origin Effect and Brand Origin Knowledge: How Little Consumers Know and How”, European Advances in Consumer Research Volume 5, 2001, pp. 325-326.

Staats, J. and Biglaiser, G. (2012), "Foreign Direct Investment in Latin America: The Importance of Judicial Strength and Rule of Law", International Studies Quarterly (2012), Vol 56, pp.193-202.

Transparency International Corruption Perceptions Index (2012), "Technical Methodology Note", Transparency International, the global coalition against corruption.

Webpage:http://www.transparency.org/files/content/pressrelease/2012_CPITechnicalM ethodologyNote_EMBARGO_EN.pdf.

UNCTAD (2009), “World Investment Report 2009”, United Nations, New York.

UNCTAD (2010), “World Investment Report 2010”, United Nations, New York

UNCTAD (2011), “World Investment Report 2011”, United Nations, New York.

UNCTAD (2012), “World Investment Report 2012”, United Nations, New York.

UNCTAD (2013), “World Investment Report 2013”, United Nations, New York.

UNCTAD (2014), “World Investment Report 2014”, United Nations, New York.

Windmeijer, Frank, (2006), "GMM for Panel Count Data Models", Department of Economics, University of Bristol, Discussion Paper No. 06/591.

Zweigert, K and Kötz, H, (1998), “An introduction to comparative law", 3rd edition translated from the German by Tony Weir, Clarendon Press, Oxford. 


\section{Appendix}

Table 1: Classification of countries by Legal and Colonial Origins (Total countries= 193 countries/regions)

\begin{tabular}{|c|c|c|c|c|c|c|c|c|}
\hline & (1) & \multirow{2}{*}{$\begin{array}{c}\text { (2) } \\
\text { Former British Colony }\end{array}$} & \multicolumn{2}{|c|}{ (3) } & \multirow{2}{*}{$\begin{array}{c}\text { (4) } \\
\text { Other Former Colony }\end{array}$} & \multirow{2}{*}{$\begin{array}{c}\text { (5) } \\
\text { Never colonized }\end{array}$} & \multirow{2}{*}{$\begin{array}{r}\text { (6) } \\
\text { No of } \\
\text { count }\end{array}$} \\
\hline & & Former French Colony & & Former Colony of Ot & vil Law Country & & & \\
\hline (1) & $\begin{array}{l}\text { French } \\
\text { Civil Law } \\
\text { Legal Origin }\end{array}$ & $\begin{array}{l}\text { Algeria } \\
\text { Andorra } \\
\text { Belgium } \\
\text { Benin } \\
\text { Burkina Faso } \\
\text { Cambodia } \\
\text { Cameroon } † \\
\text { Cote D'Ivoire } \\
\text { Congo } \\
\text { Central Africa Rep. } \\
\text { Chad } \\
\text { Comoro Island } \\
\text { Djibouti } \\
\text { French Guiana } \\
\text { French Polynes } \\
\text { Gabon } \\
\text { Guinea } \\
\text { Haiti } \\
\text { Italy } \\
\text { Laos, People's Dem } \\
\text { Madagascar } \\
\text { Mali } \\
\text { Martinique } \\
\text { Mayotte } \\
\text { Mauritania } \\
\text { Morocco } \\
\text { Netherlands } \\
\text { Niger } \\
\text { Reunion } \\
\text { Senegal } \\
\text { Togo } \\
\text { Tunisia } \\
\text { Vietnam } \\
\text { Somalia } †\end{array}$ & & $\begin{array}{l}\text { Portuguese colony } \\
\text { Angola } \\
\text { Brazil } \\
\text { Cape Verde } \\
\text { Guinea-Bissau } \\
\text { (Macao) } \\
\text { Mozambique } \\
\text { Sao tome and Prim } \\
\text { Timor-leste } \\
\\
\\
\\
\text { Spanish colony } \\
\text { Argentina } \\
\text { Bolivia } \\
\text { Chile } \\
\text { Columbia } \\
\text { Costa Rica } \\
\text { Cuba } \\
\text { Dominican Rep. } \\
\text { Ecuador } \\
\text { El Salvador } \\
\text { Equatorial Guinea } \\
\text { Guatemala } \\
\text { Honduras } \\
\text { Mexico } \\
\text { Panama } \\
\text { Paraguay } \\
\text { Peru } \\
\text { Uruguay } \\
\text { Venezuela } \\
\text { Nicaragua } \\
\end{array}$ & $\begin{array}{l}\text { Belgian colony } \\
\text { Burundi } \\
\text { Rwanda } \\
\text { Dem Rep of Congo } \\
\\
\\
\text { Dutch colony } \\
\text { Aruba } \\
\text { Indonesia } \\
\text { Suriname } \\
\text { Luxemburg } \\
\\
\text { Ottoman colony } \\
\text { Albania } \\
\text { Armenia } \\
\text { Egypt } \\
\text { Eritrea } \\
\text { Greece } \\
\text { Lebanon } \\
\text { Libya } \\
\text { Jordan } \\
\text { Iraq } \\
\text { Syria } \\
\text { Bulgaria } \\
\text { Israel } \\
\text { Oman }\end{array}$ & & $\begin{array}{l}\text { Afghanistan } \\
\text { Ethiopia } \\
\text { France } \\
\text { Iran } \\
\text { Kuwait } \\
\text { Portugal } \\
\text { Russian } \\
\text { Federation } \\
\text { Spain } \\
\text { Turkey }\end{array}$ & 90 \\
\hline (2) & $\begin{array}{l}\text { British } \\
\text { Common } \\
\text { Law legal } \\
\text { origin }\end{array}$ & & $\begin{array}{l}\text { Antigua and Barbuda } \\
\text { Australia } \\
\text { Bahamas, the } \\
\text { Bangladesh } \\
\text { Barbados } \\
\text { Belize }\end{array}$ & & & $\begin{array}{l}\text { Australian colony } \\
\text { Papua New Guinea }\end{array}$ & $\begin{array}{l}\text { Bhutan } \\
\text { Liberia } \\
\text { Maldives } \\
\text { Nepal } \\
\text { Saudi Arabia } \\
\text { United Arab Emir }\end{array}$ & 45 \\
\hline
\end{tabular}




\begin{tabular}{|c|c|c|c|c|c|}
\hline & & $\begin{array}{l}\text { Bermuda } \\
\text { Canada } \\
\text { [Quebec (Canada)] } \\
\text { Fuji } \\
\text { Gambia } \\
\text { Ghana } \\
\text { Grenada } \\
\text { (Hong Kong) } \\
\text { India } \\
\text { Ireland } \\
\text { Jamaica } \\
\text { Kenya } \\
\text { Kiribati } \\
\text { Myanmar (Burma) } \\
\text { Malawi } \\
\text { Malaysia } \\
\text { New Zealand } \\
\text { Nigeria } \\
\text { Pakistan } \\
\text { Sierra Leone } \\
\text { Singapore } \\
\text { Solomon Island } \\
\text { St. Vincent Anti } \\
\text { Sudan } \\
\text { Swaziland } \\
\text { Tokelau } \\
\text { Trinidad And Tobago } \\
\text { Tuvalu } \\
\text { Uganda } \\
\text { United States } \\
\text { [Louisiana (USA)] } † \\
\text { Zambia } \\
\text { St. Kitts-Nevis } \\
\text { Swaziland }\end{array}$ & & $\begin{array}{l}\text { United Kingdom } \\
{[\text { Scotland (UK) }] \dagger}\end{array}$ & \\
\hline (3) & $\begin{array}{l}\text { German } \\
\text { Legal Origin }\end{array}$ & & $\begin{array}{l}\text { Japanese colony } \\
\text { (Taiwan) } \\
\text { Korea, Rep. } \\
\text { Austro-Hungarian } \\
\text { Croatia } \\
\text { Czech Rep. } \\
\text { Czechoslovakia } \\
\text { Hungary } \\
\text { Liechtenstein } \\
\text { Slovak Rep. } \\
\text { Slovenia } \\
\text { Bosnia and Herzog } \\
\text { Romania }\end{array}$ & $\begin{array}{l}\text { Japan } \\
\text { Austria } \\
\text { Switzerland } \\
\text { Germany }\end{array}$ & 15 \\
\hline
\end{tabular}




\begin{tabular}{|c|c|c|c|c|c|c|}
\hline & & & & Serbia and Montenegro & & \\
\hline (6) & $\begin{array}{l}\text { Mixed Legal } \\
\text { Origin }\end{array}$ & Bahrain & $\begin{array}{l}\text { Botswana } \\
\text { Cyprus } \\
\text { Guyana } \\
\text { Lesotho } \\
\text { Malta } \\
\text { Mauritius } \\
\text { Qatar } \\
\text { Seychelles } \\
\text { South Africa } \\
\text { Sri Lanka } \\
\text { St. Lucia } \\
\text { Vanuatu } \\
\text { Zimbabwe } \\
\text { Yemen, Rep }\end{array}$ & $\begin{array}{l}\text { U.S. colony } \\
\text { Puerto Rica } \\
\text { Philippines } \\
\\
\text { South African colony } \\
\text { Namibia }\end{array}$ & Thailand & 19 \\
\hline
\end{tabular}

Source: Compiled by authors according to the integrated data provided by Professor Daniel Klerman, the co-author of Klerman et al. (2011)

( ) Hong Kong and Macau are now the Special Administrative Regions of China. Taiwan is regarded as part of China under UN classification. They are put in brackets.

$\uparrow$ Scotland, Louisiana, Quebec, Cameroon, and Somalia are regarded as 'regional hybrid' marked with $\dagger$ 
Table 2: Geographical region and composition (compiled by author)

\begin{tabular}{|c|c|c|c|c|c|c|c|c|}
\hline \multirow{4}{*}{$\begin{array}{l}\text { Sub-Saharan } \\
\text { Africa } \\
\text { (Eastern Africa + } \\
\text { Middle Africa + } \\
\text { Southern Africa + } \\
\text { Western Africa ) }\end{array}$} & Burundi & Comoros & Djibouti & Eritrea & Ethiopia & Kenya & Madagascar & Malawi \\
\hline & Mauritius & Mayotte* & Mozambique & Réunion* & Rwanda & Seychelles & Somalia & $\begin{array}{l}\text { South } \\
\text { Sudan* }\end{array}$ \\
\hline & Uganda & $\begin{array}{l}\text { United } \\
\text { Republic of } \\
\text { Tanzania }\end{array}$ & Zambia & $\begin{array}{l}\text { Democratic } \\
\text { Republic of } \\
\text { the Congo }\end{array}$ & $\begin{array}{l}\text { Equatorial } \\
\text { Guinea }\end{array}$ & Gabon & $\begin{array}{l}\text { Sao Tome } \\
\text { and Principe }\end{array}$ & $\begin{array}{l}\text { South } \\
\text { Africa }\end{array}$ \\
\hline & Swaziland & Angola & Cameron & $\begin{array}{l}\text { Central } \\
\text { African } \\
\text { Republic }\end{array}$ & Chad & Congo & Botswana & Lesotho \\
\hline \multirow{3}{*}{$\begin{array}{l}\text { Total: } \\
\text { countries/districts } \\
=51-3(\text { no FDI } \\
\text { data - marked with *) } \\
=48\end{array}$} & Namibia & Benin & Burkina Faso & Cape Verde & $\begin{array}{l}\text { Cote } \\
\text { d'Ivoire }\end{array}$ & Gambia & Ghana & Guinea \\
\hline & $\begin{array}{l}\text { Guinea- } \\
\text { Bissau }\end{array}$ & Liberia & Zimbabwe & Mali & Mauritania & Niger & Nigeria & $\begin{array}{l}\text { Saint } \\
\text { Helena* }\end{array}$ \\
\hline & Senegal & Sierra Leone & Swaziland & & & & & \\
\hline
\end{tabular}

\begin{tabular}{|c|c|c|c|c|c|c|c|c|}
\hline \multirow{3}{*}{$\begin{array}{l}\text { Americas } \\
\text { (Latin America } \\
\underline{\text { and the }} \\
\underline{\text { Caribbean) }}\end{array}$} & \multicolumn{8}{|l|}{ Caribbean } \\
\hline & Anguilla* & $\begin{array}{l}\text { Antigua and } \\
\text { Barbuda }\end{array}$ & Aruba & Bahamas & Barbados & $\begin{array}{l}\text { Bonaire, } \\
\text { Saint } \\
\text { Eustatius* }\end{array}$ & $\begin{array}{l}\text { Turks and } \\
\text { Caicos } \\
\text { Islands }\end{array}$ & $\begin{array}{l}\text { United } \\
\text { States } \\
\text { Virgin } \\
\text { Islands* }\end{array}$ \\
\hline & $\begin{array}{l}\text { Trinidad } \\
\text { and Tobago }\end{array}$ & $\begin{array}{l}\text { British Virgin } \\
\text { Islands }\end{array}$ & $\begin{array}{l}\text { Cayman } \\
\text { Islands }\end{array}$ & Cuba & Curacao & Dominica & $\begin{array}{l}\text { Dominican } \\
\text { Republic }\end{array}$ & Grenada \\
\hline \multirow{7}{*}{$\begin{array}{l}\text { Total: } \\
\text { countries/districts } \\
=50-10(\text { no FDI } \\
\text { data }- \text { marked with } *) \\
=40\end{array}$} & $\begin{array}{l}\text { Guadeloup } \\
\mathrm{e}^{*}\end{array}$ & Haiti & Jamaica & Martinique & Montserrat* & Puerto Rico & $\begin{array}{l}\text { Saint- } \\
\text { Barthélemy } \\
*\end{array}$ & $\begin{array}{l}\text { Saint Kitts } \\
\text { and Nevis }\end{array}$ \\
\hline & Saint Lucia & $\begin{array}{l}\text { Saint Martin } \\
\text { (French part)* }\end{array}$ & $\begin{array}{l}\text { Saint Vincent } \\
\text { and the } \\
\text { Grenadines }\end{array}$ & $\begin{array}{l}\text { Sint } \\
\text { Maarten } \\
\text { (Dutch } \\
\text { part)* }\end{array}$ & & & & \\
\hline & \multicolumn{8}{|c|}{ Central America } \\
\hline & Belize & Costa Rica & El Salvador & Guatemala & Honduras & Mexico & Nicaragua & Panama \\
\hline & \multicolumn{8}{|c|}{ South America } \\
\hline & Argentina & $\begin{array}{l}\text { Bolivia } \\
\text { (Plurinational } \\
\text { State of) }\end{array}$ & Brazil & Chile & Colombia & Ecuador & $\begin{array}{l}\text { Falkland } \\
\text { Islands } \\
\text { (Malvinas)* }\end{array}$ & $\begin{array}{l}\text { Venezuela } \\
\text { (Bolivarian } \\
\text { Republic } \\
\text { of) }\end{array}$ \\
\hline & $\begin{array}{l}\text { French } \\
\text { Guiana* }\end{array}$ & Guyana & Paraguay & Peru & Suriname & Uruguay & & \\
\hline
\end{tabular}

\begin{tabular}{|c|c|c|c|c|c|c|c|c|}
\hline \multirow{3}{*}{$\begin{array}{l}\text { Asia } \\
\text { Eastern Asia and } \\
\underline{\text { South-Eastern }} \\
\underline{\text { Asia }} \\
\text { Total: } \\
\text { countries/districts } \\
=18-2(\text { SAR of } \\
\text { China } \dagger \text { ) } \\
-1(\text { no FDI data- } \\
\text { marked with } *) \\
=15\end{array}$} & China & $\begin{array}{l}\text { China, Hong } \\
\text { Kong Special } \\
\text { Administrativ } \\
\text { e Region } \dagger\end{array}$ & $\begin{array}{l}\text { China, Macao } \\
\text { Special } \\
\text { Administrativ } \\
\text { e Region } \dagger\end{array}$ & $\begin{array}{l}\text { Brunei } \\
\text { Darussala } \\
\text { m }\end{array}$ & Cambodia & Indonesia & $\begin{array}{l}\text { Lao } \\
\text { People's } \\
\text { Democratic } \\
\text { Republic }\end{array}$ & Malaysia \\
\hline & Myanmar & $\begin{array}{l}\text { Democratic } \\
\text { People's } \\
\text { Republic of } \\
\text { Korea }\end{array}$ & Japan & Mongolia & $\begin{array}{l}\text { Republic of } \\
\text { Korea }\end{array}$ & Philippines & Singapore & Thailand \\
\hline & $\begin{array}{l}\text { Timor- } \\
\text { Leste* }\end{array}$ & Viet Nam & & & & & & \\
\hline \multirow{2}{*}{$\begin{array}{l}\text { Southern Asia } \\
\text { Total: } \\
\text { countries/districts } \\
=9\end{array}$} & $\begin{array}{l}\text { Afghanista } \\
\mathrm{n}\end{array}$ & Bangladesh & Bhutan & India & $\begin{array}{l}\text { Iran } \\
\text { (Islamic } \\
\text { Republic of) } \\
\end{array}$ & Maldives & Nepal & Pakistan \\
\hline & Sri Lanka & & & & & & & \\
\hline \multirow{2}{*}{$\begin{array}{l}\text { Mediterranean } \\
\text { (Western Asia } \\
\text { and North Africa) }\end{array}$} & Armenia & Azerbaijan & Bahrain & Cyprus & Georgia & Iraq & Israel & Jordan \\
\hline & Kuwait & Algeria & Egypt & Libya & Morocco & Tunisia & $\begin{array}{l}\text { Western } \\
\text { Sahara** }\end{array}$ & Sudan \\
\hline
\end{tabular}




\begin{tabular}{|c|c|c|c|c|c|c|c|c|}
\hline \multirow{3}{*}{$\begin{array}{l}\text { Total: } \\
\text { countries/districts } \\
=25-1(\text { no FDI } \\
\text { data }- \text { marked with *) } \\
=24\end{array}$} & & & & & & & & \\
\hline & Lebanon & Oman & Qatar & $\begin{array}{l}\text { Saudi } \\
\text { Arabia }\end{array}$ & $\begin{array}{l}\text { State of } \\
\text { Palestine }\end{array}$ & $\begin{array}{l}\text { Syrian Arab } \\
\text { Republic }\end{array}$ & Turkey & $\begin{array}{l}\text { United } \\
\text { Arab } \\
\text { Emirates }\end{array}$ \\
\hline & Yemen & & & & & & & \\
\hline \multirow{2}{*}{$\begin{array}{l}\text { Post-Soviet } \\
\text { States } \\
\text { (Eastern Europe } \\
\text { and Central Asia) } \\
\text { Total: } \\
\text { countries/districts } \\
=15\end{array}$} & Belarus & Bulgaria & $\begin{array}{l}\text { Czech } \\
\text { Republic }\end{array}$ & Hungary & Poland & Kazakhstan & Kyrgyzstan & Tajikistan \\
\hline & $\begin{array}{l}\text { Republic of } \\
\text { Moldova }\end{array}$ & Romania & $\begin{array}{l}\text { Russian } \\
\text { Federation }\end{array}$ & Slovakia & Ukraine & $\begin{array}{l}\text { Turkmenista } \\
\mathrm{n}\end{array}$ & Uzbekistan & \\
\hline \multirow{3}{*}{$\begin{array}{l}\text { Europe } \\
\text { North Atlantic } \\
\text { Ocean } \\
\text { (Northern Europe } \\
\text { and Northern } \\
\text { America) } \\
\text { Total: } \\
\text { countries/districts } \\
=22-9 \text { (no FDI } \\
\text { data - marked with *) } \\
=13\end{array}$} & Bermuda & Canada & Greenland & $\begin{array}{l}\text { Aland } \\
\text { Islands* }\end{array}$ & $\begin{array}{l}\text { Channel } \\
\text { Islands* }\end{array}$ & Denmark & Estonia & $\begin{array}{l}\text { Faeroe } \\
\text { Islands* }\end{array}$ \\
\hline & Finland & Guernsey* & Iceland & Ireland & $\begin{array}{l}\text { Saint Pierre } \\
\text { and } \\
\text { Miquelon* }\end{array}$ & $\begin{array}{l}\text { United } \\
\text { States of } \\
\text { America }\end{array}$ & Jersey* & Sark* \\
\hline & $\begin{array}{l}\text { Svalbard } \\
\text { and Jan } \\
\text { Mayen } \\
\text { Islands* }\end{array}$ & Sweden & $\begin{array}{l}\text { United } \\
\text { Kingdom of } \\
\text { Great Britain } \\
\text { and Northern } \\
\text { Ireland }\end{array}$ & Latvia & Lithuania* & Norway & & \\
\hline \multirow{2}{*}{$\begin{array}{l}\text { Southern Europe } \\
\text { Total: } \\
\text { countries/districts } \\
=16-4 \text { (no FDI } \\
\text { data - marked with *) } \\
=12\end{array}$} & Albania & Andorra* & $\begin{array}{l}\text { Bosnia and } \\
\text { Herzegovina }\end{array}$ & Croatia & Gibraltar & Greece & Holy See* & Italy \\
\hline & Malta & Montenegro & Portugal & $\begin{array}{l}\text { San } \\
\text { Marino* }\end{array}$ & Serbia & Slovenia & Spain & $\begin{array}{l}\text { The former } \\
\text { Yugoslav } \\
\text { Republic of } \\
\text { Macedonia } \\
*\end{array}$ \\
\hline \multirow{2}{*}{$\begin{array}{l}\text { Western Europe } \\
\text { Total: } \\
\text { countries/districts } \\
=9-1 \text { (no FDI } \\
\text { data - marked with } * \text { ) } \\
=8\end{array}$} & Austria & Belgium & France & Germany & $\begin{array}{l}\text { Liechtenstei } \\
\mathrm{n}\end{array}$ & Luxembourg & Monaco* & Netherlands \\
\hline & Switzerland & & & & & & & \\
\hline \multirow[t]{3}{*}{ Oceania } & \multicolumn{8}{|c|}{ Australia and New Zealand } \\
\hline & Australia & New Zealand & Norfolk Island & & & & & \\
\hline & \multicolumn{8}{|l|}{ Melanesia } \\
\hline \multirow{6}{*}{$\begin{array}{l}\text { Total: } \\
\text { countries/districts } \\
=25-16 \text { (no FDI } \\
\text { data - marked with } *) \\
=9\end{array}$} & Fiji & $\begin{array}{l}\text { New } \\
\text { Caledonia* }\end{array}$ & $\begin{array}{l}\text { Papua New } \\
\text { Guinea }\end{array}$ & $\begin{array}{l}\text { Solomon } \\
\text { Islands* }\end{array}$ & Vanuatu* & & & \\
\hline & \multicolumn{8}{|c|}{ Micronesia } \\
\hline & Guam* & Kiribati & $\begin{array}{l}\text { Marshall } \\
\text { Islands }\end{array}$ & $\begin{array}{l}\text { Micronesia } \\
\text { (Federated } \\
\text { States of)* }\end{array}$ & Nauru* & $\begin{array}{l}\text { Northern } \\
\text { Mariana } \\
\text { Islands* }\end{array}$ & Palau* & \\
\hline & \multicolumn{8}{|l|}{ Polynesia } \\
\hline & $\begin{array}{l}\text { American } \\
\text { Samoa* }\end{array}$ & Cook Islands* & $\begin{array}{l}\text { French } \\
\text { Polynesia }\end{array}$ & Niue* & Pitcairn* & Samoa* & Tokelau* & Tonga* \\
\hline & Tuvalu* & $\begin{array}{l}\text { Wallis and } \\
\text { Futuna } \\
\text { Islands* }\end{array}$ & & & & & & \\
\hline Grand total & \multicolumn{8}{|c|}{$=48+40+15+9+24+15+13+12+8+9=193$ countries $/$ districts } \\
\hline
\end{tabular}

\section{Compiled by author-sourced from:-}

United Nations Statistics Division (UNdata)

Note: The countries/district marked with asterisk* are being opted out from our analysis sample due to lack of available FDI data for these countries 
Table 3: Definitions of Variables

\begin{tabular}{|c|c|c|c|}
\hline \multicolumn{2}{|l|}{ Variable } & \multirow{2}{*}{$\begin{array}{l}\text { Definition } \\
\text { Inflows of FDI (US\$) }\end{array}$} & \multirow{2}{*}{$\begin{array}{l}\text { Source } \\
\text { World Bank Statistics }\end{array}$} \\
\hline \multirow{4}{*}{ FDI Measure } & FDI inflow & & \\
\hline & FDI Inflow/GDP & Inflows of FDI (US\$)/GDP & World Bank Statistics \\
\hline & FDI Net & Net value of FDI (US\$) & World Bank Statistics \\
\hline & FDI Net/ GDP & Net value of FDI (US\$)/GDP & World Bank Statistics \\
\hline \multirow{5}{*}{ Institutions } & $\begin{array}{l}\text { ICRG rule of law } \\
\text { (Law and order) }\end{array}$ & $\begin{array}{l}\text { Index of intellectual Property } \\
\text { Rights Protection *Law and order } \\
\text { (assessment of the strength and } \\
\text { impartiality of legal system) }\end{array}$ & $\begin{array}{l}\text { International Country } \\
\text { Risk Guide (ICRG) - } \\
\text { The PRS Group (2012) }\end{array}$ \\
\hline & $\begin{array}{l}\text { Corruption Perception } \\
\text { Index (CPI) }\end{array}$ & $\begin{array}{l}\text { An assessment of corruption within } \\
\text { the political system that distorts the } \\
\text { economic and financial } \\
\text { environment, reduces the } \\
\text { efficiency }\end{array}$ & $\begin{array}{l}\text { International Country } \\
\text { Risk Guide (ICRG) - } \\
\text { The PRS Group (2012) }\end{array}$ \\
\hline & Bureaucracy Quality & $\begin{array}{l}\text { An assessment of possible drastic } \\
\text { policy changes when governments } \\
\text { change. Strong bureaucracy has the } \\
\text { strength and expertise to govern } \\
\text { without drastic changes in policy } \\
\text { or interruptions in government } \\
\text { services }\end{array}$ & $\begin{array}{l}\text { International Country } \\
\text { Risk Guide (ICRG) - } \\
\text { The PRS Group (2012) }\end{array}$ \\
\hline & Government Stability & $\begin{array}{l}\text { An assessment of the government's } \\
\text { ability to carry out its declared } \\
\text { program(s) and its ability to stay in } \\
\text { office based on criteria like } \\
\text { government unity, legislative } \\
\text { strength }\end{array}$ & $\begin{array}{l}\text { International Country } \\
\text { Risk Guide (ICRG) - } \\
\text { The PRS Group (2012) }\end{array}$ \\
\hline & Polity IV & $\begin{array}{l}\text { Measures key qualities in } \\
\text { executive recruitment, } \\
\text { constraints on executives, and } \\
\text { political competition. It gives an } \\
\text { indication of whether a regime } \\
\text { is an institutionalised } \\
\text { democracy or institutionalised } \\
\text { autocracy or anocracies (mixed, } \\
\text { or incoherent, authority regimes) }\end{array}$ & $\begin{array}{l}\text { Marshall and Jaggers } \\
\text { (2012) }\end{array}$ \\
\hline \multicolumn{2}{|l|}{ Legal Origins } & $\begin{array}{l}\text { Classification of Legal families } \\
\text { under the theory of LLSV (1997, } \\
1998,2008)\end{array}$ & CIA Fact Book \\
\hline \multicolumn{2}{|c|}{ Colonial Powers } & $\begin{array}{l}\text { Classification of Legal families } \\
\text { under Klerman's (2011) colonial } \\
\text { powers theory }\end{array}$ & $\begin{array}{l}\text { Coding compiled by } \\
\text { author according to the } \\
\text { integrated data } \\
\text { provided by Professor } \\
\text { Daniel Klerman }\end{array}$ \\
\hline \multicolumn{2}{|c|}{ Judiciary Independence } & $\begin{array}{l}\text { Proxy for enforcement of law } \\
\text { through independent judges and } \\
\text { impartial courts }\end{array}$ & $\begin{array}{l}\text { 'Economic Freedom of } \\
\text { the World (EWF)' } \\
\text { provided by the Fraser } \\
\text { Institute }\end{array}$ \\
\hline \multicolumn{2}{|c|}{$\begin{array}{l}\text { Human Capital } \\
\text { (Average Secondary School 15) }\end{array}$} & Proxy for Human Capital & $\begin{array}{l}\text { Barro and Lees } \\
\text { (1994) }\end{array}$ \\
\hline
\end{tabular}




\begin{tabular}{|l|l|l|}
\hline & & \\
\hline $\begin{array}{l}\text { Infrastructure } \\
\text { (Fixed Line Telephones) }\end{array}$ & $\begin{array}{l}\text { Telephone lines (per 100 people): } \\
\text { Proxy for the state of infrastructure } \\
\text { in a country }\end{array}$ & World Bank Statistics \\
\hline Trade Openness & $\begin{array}{l}\text { Measured by the ratio of the sum } \\
\text { of exports and imports to GDP }\end{array}$ & World Bank Statistics \\
\hline $\begin{array}{l}\text { Wealth } \\
\text { (Measured by real GDP per Capita) }\end{array}$ & $\begin{array}{l}\text { A monetary measure which } \\
\text { includes the sum of natural, human } \\
\text { and physical assets. }\end{array}$ & World Bank Statistics \\
\hline M2/ GDP & $\begin{array}{l}\text { Money and quasi-money (M2) as } \\
\% \text { of GDP }\end{array}$ & World Bank Statistics \\
\hline Inflation rate & $\begin{array}{l}\text { Nominal Interest rate minus the } \\
\text { real interest rate }\end{array}$ & World Bank Statistics \\
\hline 'Mortality Settlers' & $\begin{array}{l}\text { Mortality Data which measures } \\
\text { Deaths by Broad Age group: both } \\
\text { sex }\end{array}$ & $\begin{array}{l}\text { United Nations } \\
\text { Stistics (World }\end{array}$ \\
\hline Indices of Fractionalization & $\begin{array}{l}\text { Measurement of religion, ethnicity, } \\
\text { and language }\end{array}$ & $\begin{array}{l}\text { Journal of Economic } \\
\text { Growth. }\end{array}$ \\
\hline
\end{tabular}


Table 4 : the correlation between foreign direct investment in the legal-families under Legal Origins and Colonial Powers Classification

\begin{tabular}{|c|c|c|c|c|c|c|c|c|c|c|c|c|c|c|c|c|}
\hline \multicolumn{17}{|c|}{ FDI inflows } \\
\hline & & \multicolumn{4}{|c|}{$\begin{array}{l}\text { (1) FDI Inflows (2) FDI Net } \\
\text { (7) Transition economy } \\
\text { (12) Spanish French }\end{array}$} & \multicolumn{5}{|c|}{$\begin{array}{l}\text { (3) Latin America and the Caribbean (4) Middle } \\
\begin{array}{ll}\text { (8) British Common Law } & \text { (9) French Civil Law } \\
\text { (13) Dutch Colony } & \text { (14) Mixed-English }\end{array}\end{array}$} & \multicolumn{6}{|c|}{$\begin{array}{l}\text { East (5) South Asia } \\
\text { (10) Former French Sub-Sahara } \\
\text { (15) Judiciary independence }\end{array}$} \\
\hline & & (1) & (2) & (3) & (4) & (5) & (6) & (7) & (8) & (9) & (10) & (11) & (12) & (13) & (14) & (15) \\
\hline \multirow{7}{*}{$\begin{array}{l}\text { FDI } \\
\text { Measure }\end{array}$} & $\begin{array}{l}\text { FDI } \\
\text { Inflow }\end{array}$ & 1 & & & & & & & & & & & & & & \\
\hline & FDI Net & 0.39 & 1 & & & & & & & & & & & & & \\
\hline & $\begin{array}{l}\text { FDI } \\
\text { Inflows }\end{array}$ & -0.02 & 0.00 & 1 & & & & & & & & & & & & \\
\hline & $\begin{array}{l}\text { FDI } \\
\text { Inflows }\end{array}$ & -0.14 & 0.89 & -0.19 & 1 & & & & & & & & & & & \\
\hline & $\begin{array}{l}\text { FDI } \\
\text { Inflows }\end{array}$ & -0.02 & 0.29 & -0.02 & -0.07 & 1 & & & & & & & & & & \\
\hline & $\begin{array}{l}\text { FDI } \\
\text { Inflows }\end{array}$ & -0.29 & -0.29 & -0.24 & -0.1 & -0.09 & 1 & & & & & & & & & \\
\hline & $\begin{array}{l}\text { FDI } \\
\text { Inflows }\end{array}$ & 0.11 & 0.05 & -0.08 & -0.03 & -0.03 & -0.05 & 1 & & & & & & & & \\
\hline \multirow{2}{*}{$\begin{array}{l}\text { Legal } \\
\text { Families } \\
\text { (under Legal } \\
\text { Origins } \\
\text { classification) }\end{array}$} & $\begin{array}{l}\text { British } \\
\text { Common }\end{array}$ & -0.22 & -0.28 & -0.41 & -0.24 & $\underline{0.16}$ & $\underline{0.44}$ & -0.11 & 1 & & & & & & & \\
\hline & $\begin{array}{l}\text { French } \\
\text { Civil Law }\end{array}$ & 0.02 & 0.07 & $\underline{0.52}$ & 0.28 & -0.11 & -0.26 & 0.13 & -0.70 & 1 & & & & & & \\
\hline \multirow{5}{*}{$\begin{array}{l}\text { Legal } \\
\text { Families } \\
\text { (under } \\
\text { Colonial } \\
\text { Powers } \\
\text { classification) }\end{array}$} & $\begin{array}{l}\text { Former } \\
\text { French }\end{array}$ & 0.13 & 0.08 & $\underline{-0.12}$ & 0.31 & -0.05 & -0.07 & -0.02 & -0.15 & 0.15 & 1 & & & & & \\
\hline & $\begin{array}{l}\text { Portuguese } \\
\text { Colony }\end{array}$ & 0.19 & 0.24 & 0.28 & -0.05 & -0.04 & -0.06 & -0.02 & -0.11 & 0.18 & -0.03 & 1 & & & & \\
\hline & $\begin{array}{l}\text { Spanish } \\
\text { French }\end{array}$ & -0.06 & 0.01 & $\underline{0.86}$ & -0.18 & 0.02 & -0.2 & -0.07 & -0.47 & 0.56 & -0.10 & -0.09 & 1 & & & \\
\hline & $\begin{array}{l}\text { Dutch } \\
\text { Colony }\end{array}$ & N.A & N.A & N.A & N.A & N.A & N.A & N.A & N.A & N.A & N.A & N.A & N.A & 1 & & \\
\hline & $\begin{array}{l}\text { Mixed- } \\
\text { English }\end{array}$ & -0.10 & -0.12 & -0.16 & -0.07 & -0.06 & 0.37 & -0.03 & 0.30 & -0.11 & -0.05 & -0.04 & -0.14 & N.A & 1 & \\
\hline \multicolumn{2}{|c|}{ Judiciary independence } & 0.27 & 0.16 & -0.26 & 0.07 & -0.06 & 0.09 & -0.11 & 0.38 & -0.40 & 0.05 & 0.17 & $\underline{-0.52}$ & N.A & 0.17 & 1 \\
\hline
\end{tabular}


(Group A)

Table 5: System GMM regression of levels of FDI Inflows to countries by regions classified by Legal Origins theory

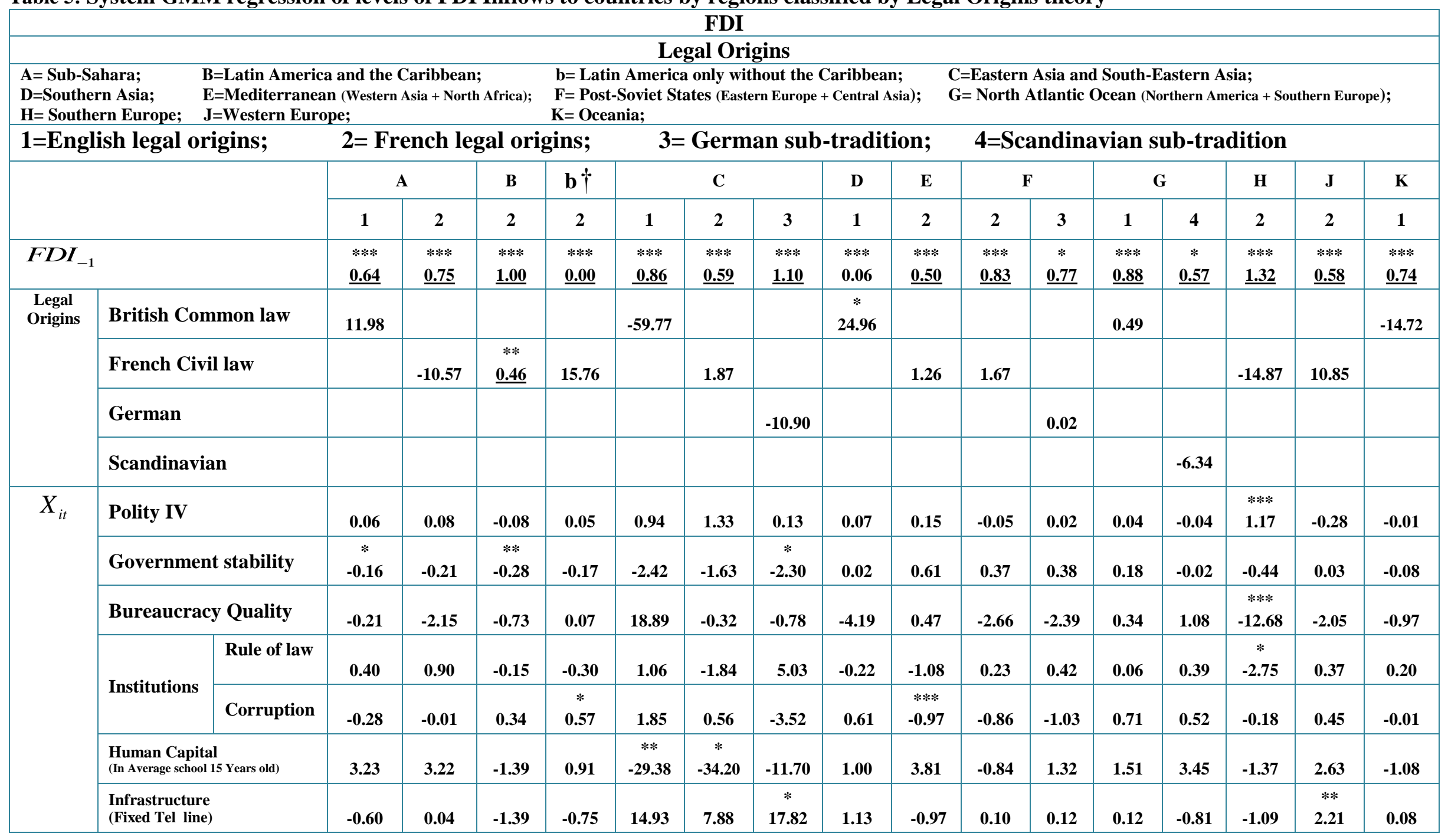




\begin{tabular}{|c|c|c|c|c|c|c|c|c|c|c|c|c|c|c|c|c|}
\hline Trade Openness & 1.11 & -3.25 & 0.73 & -0.94 & $\begin{array}{c}* \\
22.92 \\
\end{array}$ & 25.63 & $\begin{array}{c}* * * * \\
23.48 \\
\end{array}$ & 0.85 & $\begin{array}{c}* \\
-2.86 \\
\end{array}$ & -1.41 & -2.80 & 1.38 & 1.13 & **** & -5.88 & 0.12 \\
\hline Wealth (GDP per capita) & -1.64 & -1.71 & 1.11 & 1.49 & 5.86 & -2.04 & -0.96 & -0.54 & 2.31 & $\begin{array}{c}* \\
5.97\end{array}$ & 7.12 & 0.39 & 4.21 & $\begin{array}{c}* * \\
8.55\end{array}$ & $\begin{array}{l}* * * \\
3.89\end{array}$ & 0.49 \\
\hline M2/GDP & -1.68 & -0.33 & 0.21 & 1.55 & -23.88 & -5.03 & -27.26 & 0.44 & $\begin{array}{c}* * \\
-2.87\end{array}$ & -2.26 & -2.91 & 1.81 & -4.40 & $\begin{array}{c}* * * \\
-13.23\end{array}$ & -0.03 & 0.40 \\
\hline Inflation & 0.67 & 0.52 & $\mathbf{0 . 2 3}$ & 0.13 & 0.41 & 5.97 & -0.95 & 012 & 0.09 & $\begin{array}{c}* \\
0.73\end{array}$ & 0.73 & 0.10 & 0.22 & -0.14 & 0.15 & 0.09 \\
\hline Number of Instruments & 19 & 19 & 20 & 20 & 19 & 19 & 19 & 19 & 20 & 19 & 19 & 19 & 19 & 19 & 19 & 19 \\
\hline $\begin{array}{l}\text { Number of Country } \\
\text { (Total: 193) }\end{array}$ & \multicolumn{2}{|c|}{48} & \multicolumn{2}{|c|}{40} & \multicolumn{3}{|c|}{15} & 9 & 24 & \multicolumn{2}{|c|}{15} & \multicolumn{2}{|c|}{13} & 12 & 8 & 9 \\
\hline Observations & 53 & 53 & 70 & 51 & 47 & 47 & 47 & 55 & 51 & 49 & 49 & 52 & 52 & 40 & 45 & 44 \\
\hline AR1 (p-value) & 0.711 & 0.802 & 0.730 & 0.599 & 0.415 & 0.368 & 0.964 & 0.829 & 0.289 & 0.763 & 0.995 & $\mathbf{0 . 3 6 0}$ & 0.543 & 0.560 & 0.996 & 0.9110 \\
\hline Wald statistic & $\mathbf{0}$ & $\mathbf{0}$ & $\mathbf{0}$ & $\mathbf{0}$ & $\mathbf{0}$ & $\mathbf{0}$ & $\mathbf{0}$ & $\mathbf{0}$ & $\mathbf{0}$ & $\mathbf{0}$ & $\mathbf{0}$ & $\mathbf{0}$ & $\mathbf{0}$ & $\mathbf{0}$ & $\mathbf{0}$ & $\mathbf{0}$ \\
\hline Hansen p-value & 0.9704 & 0.9669 & 0.905 & 0.941 & 0.524 & 0.616 & 0.420 & 0.999 & 0.520 & 0.996 & 0.892 & 0.808 & 0.910 & 0.968 & 1.000 & 0.9823 \\
\hline $\begin{array}{l}\text { GMM instruments for levels: } \\
\text { difference (null H = exogenous) }\end{array}$ & 1.000 & 1.000 & 1.000 & 1.000 & 1.000 & 1.000 & 1.000 & 1.000 & 1.000 & 1.000 & 1.000 & 1.000 & 1.000 & 1.000 & 1.000 & 1.000 \\
\hline GMM ((ln corruption index, $\operatorname{lag}(1))$ & 1.000 & 1.000 & 1.000 & 1.000 & 1.000 & 1.000 & 1.000 & 1.000 & 1.000 & 1.000 & 1.000 & 1.000 & 1.000 & 1.000 & 1.000 & 1.000 \\
\hline $\begin{array}{l}\text { Hansen test excluding group: } \\
\text { Difference (null } \mathbf{H}=\text { exogenous) }\end{array}$ & 1.000 & 1.000 & 1.000 & 1.000 & 1.000 & 1.000 & 1.000 & 1.000 & 1.000 & 1.000 & 1.000 & 1.000 & 1.000 & 1.000 & 1.000 & 1.000 \\
\hline Legal families & 1 & 2 & 2 & 2 & 1 & 2 & 3 & 1 & 2 & 2 & 3 & 1 & 4 & 2 & 2 & 1 \\
\hline Regions/districts & & & B & $\mathbf{b} \dagger$ & & $\mathbf{C}$ & & D & $\mathbf{E}$ & & & & & $\mathbf{H}$ & $\mathbf{J}$ & $\mathbf{K}$ \\
\hline \multicolumn{17}{|c|}{$\begin{array}{l}\text { Note: (1) Confidence level: } * * *, * * \text {, and } * \text { indicate that the coefficient is significantly different from zero at th } \\
\text { (2) } \uparrow \text { We specifically put the countries of Central America and South America in group (b), which exclu } \\
\text { FDI activities solely in those larger countries in the continents } \\
\text { (3) The corresponding figures taken to support our analytic results are underlined for easier reference } \\
\text { (4) } \Delta \text { The total number of countries in the world }=\text { the sum of the countries in each of the regions }=48-\end{array}$} \\
\hline
\end{tabular}


(Group A)

Table 6: System GMM regression of levels of FDI Inflows to countries by regions classified by Colonial Powers theory

\begin{tabular}{|c|c|c|c|c|c|c|c|c|c|c|c|c|c|c|c|c|c|c|c|c|c|c|}
\hline \multicolumn{23}{|c|}{ 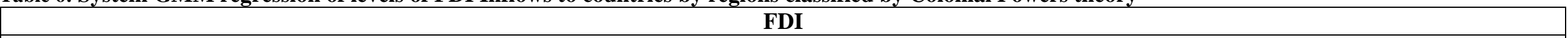 } \\
\hline \multicolumn{23}{|c|}{ 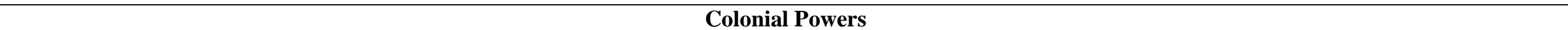 } \\
\hline \multicolumn{6}{|c|}{$\begin{array}{l}\text { A= Sub-Sahara; } \quad \text { B=Latin America and the Caribbean; } \\
\text { F= Post-Soviet States (Eastern Europe + Central Asia); } \\
\text { J= Western Europe; K= Oceania }\end{array}$} & \multicolumn{9}{|c|}{$\begin{array}{l}\text { C=Eastern Asia and South-Eastern Asia; D=Southern Asia; } \\
\text { G=North Atlantic Ocean (Northern America + Southern Europe); }\end{array}$} & \multicolumn{8}{|c|}{$\begin{array}{l}\text { E=Mediterranean (Western Asia +North Africa); } \\
\text { H=Southern Europe }\end{array}$} \\
\hline \multirow{3}{*}{\multicolumn{2}{|c|}{$\begin{array}{l}\text { 1= Former English; } \\
\text { 8= Ottoman Colony; }\end{array}$}} & $\begin{array}{l}=\text { Former } \\
=\text { Spanish }\end{array}$ & $\begin{array}{l}\text { Frencl } \\
\text { colony }\end{array}$ & $\begin{array}{r}3=S \\
\text { xcludir }\end{array}$ & $\begin{array}{l}\text { anish C } \\
\text { the Ca }\end{array}$ & $\begin{array}{l}\text { olony; } \\
\text { ribbea }\end{array}$ & $\begin{aligned} 4 & =\mathrm{P} \\
10 & =\mathrm{D}\end{aligned}$ & rtug & $\begin{array}{l}\text { e Colo } \\
\text { ony; }\end{array}$ & \multicolumn{5}{|c|}{$\begin{aligned} 5 & =\text { German never colonised; } \\
11 & =\text { mixed legal origin }\end{aligned}$} & $\begin{array}{l}\text { Japan } \\
\text { others }\end{array}$ & Colo & \multicolumn{6}{|c|}{$7=$ Austro-Hungarian } \\
\hline & & \multicolumn{4}{|c|}{ A } & \multicolumn{5}{|c|}{ B } & \multicolumn{4}{|c|}{$\mathbf{C}$} & D & $\mathbf{E}$ & \multicolumn{2}{|c|}{$\mathbf{F}$} & \multirow{2}{*}{$\begin{array}{c}\mathbf{G} \\
\mathbf{1}\end{array}$} & \multirow{2}{*}{$\begin{array}{c}\mathbf{H} \\
2\end{array}$} & \multirow{2}{*}{$\frac{\mathbf{J}}{\mathbf{2}}$} & \multirow{2}{*}{$\begin{array}{c}\mathbf{K} \\
\mathbf{1}\end{array}$} \\
\hline & & 11 & 4 & 2 & 1 & 1 & 3 & 4 & 9 & 10 & 5 & 1 & 6 & 12 & 1 & 8 & 7 & 12 & & & & \\
\hline & $F D I_{-1}$ & $\begin{array}{l}* * * * \\
\mathbf{0 . 7 1}\end{array}$ & $\begin{array}{l}* * * * \\
0.87\end{array}$ & $\begin{array}{l}* * * \\
\underline{0.88}\end{array}$ & $\begin{array}{l}* * * * \\
\underline{0.76}\end{array}$ & $\begin{array}{l}* * * * \\
\underline{0.91}\end{array}$ & $\begin{array}{c}* * * \\
0.69\end{array}$ & $\begin{array}{l}* * * * \\
1.23\end{array}$ & $\begin{array}{l}* * * * \\
0.62\end{array}$ & $\begin{array}{r}* * * * \\
\underline{0.98}\end{array}$ & $\begin{array}{r}* * * * \\
\underline{0.65}\end{array}$ & $\begin{array}{l}* * * \\
\mathbf{0 . 7 6} \\
\end{array}$ & $\begin{array}{l}* * * * \\
\underline{0.65} \\
\end{array}$ & $\begin{array}{l}* * * * \\
0.92 \\
\end{array}$ & $\begin{array}{l}* * * \\
0.75\end{array}$ & $\begin{array}{l}* * * \\
1.02\end{array}$ & $\begin{array}{l}* * * \\
0.95\end{array}$ & $\begin{array}{c}* * \\
0.17\end{array}$ & $\begin{array}{l}* * * * \\
0.64 \\
\end{array}$ & $\begin{array}{l}* * * \\
1.50 \\
\end{array}$ & $\begin{array}{l}* * * * \\
0.51 \\
\end{array}$ & $\begin{array}{l}* * * \\
0.74 \\
\end{array}$ \\
\hline \multirow[t]{11}{*}{$\begin{array}{l}\text { Colonia } \\
1 \\
\text { Powers }\end{array}$} & Former English & & & & -4.01 & -6.03 & & & & & & -27.28 & & & 12.05 & & & & $\begin{array}{l}* * * \\
4.24 \\
\end{array}$ & & & -28.38 \\
\hline & Former French & & & 5.46 & & & & & & & & & & & & & & & & -26.71 & 2.23 & \\
\hline & Spanish colony & & & & & & $\begin{array}{c}* * * \\
\underline{11.21} \\
\end{array}$ & & & & & & & & & & & & & & & \\
\hline & Portuguese colony & & -0.82 & & & & & -11.8 & & & & & & & & & & & & & & \\
\hline & $\begin{array}{l}\text { German never } \\
\text { colonised }\end{array}$ & & & & & & & & & & -0.02 & & & & & & & & & & & \\
\hline & $\begin{array}{l}\text { Austro- } \\
\text { Hungarian }\end{array}$ & & & & & & & & & & & & & & & & 5.92 & & & & & \\
\hline & Ottoman colony & & & & & & & & & & & & & & & 4.79 & & & & & & \\
\hline & $\begin{array}{l}\text { Spanish colony } \\
\text { excluding the } \\
\text { Caribhean }\end{array}$ & & & & & & & & $\begin{array}{l}* * * * \\
\underline{8.95} \\
\end{array}$ & & & & & & & & & & & & & \\
\hline & Dutch colony & & & & & & & & & 1.92 & & & & & & & & & & & & \\
\hline & Mixed legal origin & 3.98 & & & & & & & & & & & & & & & & & & & & \\
\hline & Others & & & & & & & & & & & & & $\begin{array}{c}* * * \\
10.12 \\
\end{array}$ & & & & $\begin{array}{c}* * * \\
15.49 \\
\end{array}$ & & & & \\
\hline \multirow[t]{3}{*}{$X_{i t}$} & Polity IV & 0.10 & 0.03 & 0.12 & 0.09 & -0.07 & $\begin{array}{l}* * * * \\
-0.21\end{array}$ & -0.20 & -0.00 & $-\mathbf{0 . 0 3}$ & 1.35 & 0.04 & 1.36 & -0.07 & 0.12 & 0.26 & -0.67 & $\begin{array}{c}* * \\
-0.59\end{array}$ & 1.31 & $\begin{array}{l}* * * \\
2.50\end{array}$ & -0.03 & -0.00 \\
\hline & Bureaucracy & -0.95 & -0.54 & 0.00 & -1.09 & -1.43 & 1.21 & 0.93 & -0.19 & -0.91 & -0.38 & 1.23 & -0.38 & 1.46 & 12.69 & 1.33 & $\begin{array}{c}* * * \\
-12.40\end{array}$ & $\begin{array}{c}* * * \\
-2.48\end{array}$ & 5.31 & $\begin{array}{l}* * * \\
-24.56\end{array}$ & 0.04 & -0.97 \\
\hline & $\begin{array}{l}\text { Government } \\
\text { stability }\end{array}$ & -0.15 & -0.12 & -0.19 & -0.11 & -0.30 & -0.20 & -0.16 & -0.07 & -0.23 & -1.53 & -0.11 & -1.53 & 0.41 & -0.41 & 0.62 & -0.14 & 0.23 & 0.46 & $\begin{array}{l}* * * \\
1.22\end{array}$ & 0.07 & -0.08 \\
\hline
\end{tabular}




\begin{tabular}{|c|c|c|c|c|c|c|c|c|c|c|c|c|c|c|c|c|c|c|c|c|c|c|}
\hline \multirow{2}{*}{\begin{tabular}{l|l} 
& \\
Instituti \\
ons
\end{tabular}} & $\begin{array}{l}\text { Rule of } \\
\text { law }\end{array}$ & 0.58 & 0.28 & 0.96 & -0.27 & -0.27 & -0.05 & 1.03 & -0.34 & -0.27 & -2.25 & -0.52 & -2.25 & 0.22 & -1.47 & -1.11 & 0.32 & $\begin{array}{c}* \\
1.08 \\
\end{array}$ & 0.60 & $\begin{array}{c}* \\
0.81 \\
\end{array}$ & 0.49 & 0.20 \\
\hline & $\begin{array}{l}\text { Corrupt } \\
\text { ion }\end{array}$ & -0.08 & 0.15 & -0.12 & 0.16 & $\begin{array}{c}* \\
0.51\end{array}$ & $\mathbf{0 . 3 9}$ & 0.18 & 0.27 & $\mathbf{0 . 3 7}$ & 0.70 & 0.15 & 0.70 & -0.58 & 2.10 & -0.86 & 0.28 & $\begin{array}{c}* * * \\
-1.06\end{array}$ & -0.07 & 0.29 & -0.07 & -0.01 \\
\hline \multicolumn{2}{|c|}{\begin{tabular}{|l|} 
Human Capital \\
In Average school 15 \\
Years old
\end{tabular}} & 3.69 & 1.62 & -2.00 & 3.46 & $\begin{array}{c}* \\
-2.45 \\
\end{array}$ & -2.57 & -2.31 & -0.39 & -0.92 & $\begin{array}{c}* \\
-34.47 \\
\end{array}$ & -5.54 & 2.21 & 17.78 & -13.85 & 3.22 & -3.14 & -1.31 & 8.97 & $\begin{array}{ll}* * * * \\
36.21 \\
\end{array}$ & -0.79 & -1.08 \\
\hline \multicolumn{2}{|c|}{$\begin{array}{l}\text { Infrastructure } \\
\text { (Fixed Tel line) }\end{array}$} & -0.36 & 0.34 & 0.36 & -0.19 & -1.67 & 0.09 & -0.63 & -0.02 & 0.30 & 0.735 & 1.07 & $\begin{array}{c}* \\
7.47 \\
\end{array}$ & -2.38 & 3.20 & -0.44 & $\begin{array}{c}* \\
3.09\end{array}$ & 3.08 & $\begin{array}{c}* * * \\
12.40\end{array}$ & -0.29 & 1.36 & 0.08 \\
\hline \multicolumn{2}{|c|}{ Trade Openness } & -0.29 & 2.45 & 2.14 & -0.09 & $\begin{array}{c}* \\
1.62\end{array}$ & 0.80 & 0.06 & -0.12 & 0.59 & 23.20 & 3.37 & 23.21 & -2.37 & 3.20 & 2.92 & 3.80 & 5.13 & $\begin{array}{c}* * \\
5.08\end{array}$ & $\begin{array}{l}* * * * \\
4.25\end{array}$ & -0.93 & 0.12 \\
\hline \multicolumn{2}{|c|}{$\begin{array}{l}\text { Wealth (GDP } \\
\text { per capita) }\end{array}$} & -2.68 & -2.34 & -0.16 & -2.74 & 1.26 & 2.73 & 1.03 & 0.00 & 0.72 & -1.63 & -0.66 & -2.05 & 1.02 & -3.04 & 2.46 & 12.05 & 16.69 & 0.28 & $\begin{array}{c}* * \\
10.33 \\
\end{array}$ & $\begin{array}{l}* * * * \\
3.38 \\
\end{array}$ & 0.49 \\
\hline \multicolumn{2}{|c|}{ M2/GDP } & -1.85 & -2.84 & -1.58 & -1.95 & 0.97 & -0.28 & -0.01 & 0.10 & 0.21 & -4.12 & 0.64 & -4.12 & -4.03 & -3.04 & -4.31 & $\begin{array}{c}* * * \\
-9.98 \\
\end{array}$ & $\begin{array}{c}* * * \\
-12.95 \\
\end{array}$ & -1.03 & $\begin{array}{c}* * * \\
-29.59 \\
\end{array}$ & -0.55 & 0.40 \\
\hline \multicolumn{2}{|c|}{ Inflation } & 0.49 & 0.46 & 0.17 & 0.52 & 0.25 & 0.09 & 0.57 & 0.03 & $\mathbf{0 . 3 0}$ & 5.73 & -0.14 & 5.73 & -0.89 & 0.17 & 0.17 & $\begin{array}{l}* * * \\
0.74\end{array}$ & $\begin{array}{c}* * \\
1.05\end{array}$ & 0.38 & $\begin{array}{c}* * * \\
-1.23\end{array}$ & $\begin{array}{c}* \\
0.32\end{array}$ & 0.09 \\
\hline \multicolumn{2}{|c|}{ Number of Instruments } & 19 & 19 & 19 & 19 & 19 & 19 & 19 & 19 & 19 & 19 & 18 & 19 & 19 & 19 & 19 & 20 & 19 & 19 & 19 & 15 & 19 \\
\hline \multicolumn{2}{|c|}{$\begin{array}{l}\text { Number of Country } \Delta \\
\text { (Total: 193) }\end{array}$} & \multicolumn{4}{|c|}{48} & \multicolumn{5}{|c|}{40} & \multicolumn{4}{|c|}{15} & 9 & 24 & \multicolumn{2}{|c|}{15} & 13 & 12 & 8 & 9 \\
\hline \multicolumn{2}{|c|}{ Observations } & 54 & 54 & 54 & 54 & 70 & 70 & 70 & 51 & 70 & 47 & 47 & 47 & 47 & 55 & 51 & 41 & 41 & 52 & 40 & 45 & 44 \\
\hline \multicolumn{2}{|l|}{ AR1 (p-value) } & 0.891 & 0.922 & 0.899 & 0.932 & 0.956 & 0.787 & 0.766 & 0,501 & 0.964 & 0.429 & 0.410 & 0.859 & 0.797 & 0.405 & 0.564 & 0.434 & 0.824 & 0.724 & 0.968 & 0.902 & 0.799 \\
\hline \multicolumn{2}{|l|}{ Wald statistic } & $\mathbf{0}$ & $\mathbf{0}$ & $\mathbf{0}$ & $\mathbf{0}$ & $\mathbf{0}$ & $\mathbf{0}$ & $\mathbf{0}$ & $\mathbf{0}$ & $\mathbf{0}$ & $\mathbf{0}$ & $\mathbf{0}$ & $\mathbf{0}$ & $\mathbf{0}$ & $\mathbf{0}$ & $\mathbf{0}$ & $\mathbf{0}$ & $\mathbf{0}$ & $\mathbf{0}$ & $\mathbf{0}$ & $\mathbf{0}$ & 0 \\
\hline \multicolumn{2}{|c|}{ Hansen p-value } & 0.893 & 0.904 & 0.879 & 0.992 & 0.927 & 0.923 & 0.956 & 0.948 & 0.420 & 0.600 & 0.562 & 1.000 & 0.722 & 0.601 & 0.982 & 0.745 & 0.884 & 0.962 & 1.000 & 0.990 & 0.896 \\
\hline \multicolumn{2}{|c|}{$\begin{array}{l}\text { GMM instruments for levels: } \\
\text { difference (null } \mathrm{H}=\text { exogenous) }\end{array}$} & 1.000 & 1.000 & 1.000 & 1.000 & 1.000 & 1.000 & 1.000 & 1.000 & 1.000 & 1.000 & 1.000 & 1.000 & 1.000 & 1.000 & 1.000 & 1.000 & 1.000 & 1.000 & 1.000 & 1.000 & 1.000 \\
\hline \multicolumn{2}{|c|}{$\begin{array}{l}\text { GMM (In corruption } \\
\text { index, lag 1) }\end{array}$} & 1.000 & 1.000 & 1.000 & 1.000 & 1.000 & 1.000 & 1.000 & 1.000 & 1.000 & 1.000 & 1.000 & 1.000 & 1.000 & 1.000 & 1.000 & 1.000 & 1.000 & 1.000 & 1.000 & 1.000 & 1.000 \\
\hline \multicolumn{2}{|c|}{$\begin{array}{l}\text { Hansen test excluding group: } \\
\text { Difference (null H = exogenous) }\end{array}$} & 1.000 & 1.000 & 1.000 & 1.000 & 1.000 & 1.000 & 1.000 & 1.000 & 1.000 & 1.000 & 1.000 & 1.000 & 1.000 & 1.000 & 1.000 & 1.000 & 1.000 & 1.000 & 1.000 & 1.000 & 1.000 \\
\hline \multicolumn{2}{|l|}{ Legal families } & 11 & 4 & 2 & 1 & 1 & 3 & 4 & 9 & 10 & 5 & 1 & 6 & 12 & 1 & 8 & 7 & 12 & 1 & 2 & 2 & 1 \\
\hline \multicolumn{2}{|c|}{ Regions/districts } & \multicolumn{4}{|c|}{ A } & \multicolumn{5}{|c|}{ B } & \multicolumn{4}{|c|}{ C } & D & $\mathbf{E}$ & \multicolumn{2}{|c|}{$\mathbf{F}$} & G & $\mathbf{H}$ & $\mathbf{J}$ & $\mathbf{K}$ \\
\hline
\end{tabular}

Note: (1) Confidence level: ***,**, and* indicate that the coefficient is significantly different from zero at the $1 \%, 5 \%$ and $10 \%$ respectively

(2) The corresponding figures taken to support our analytic results are underlined for easier reference

(3) ${ }^{\Delta}$ The total number of countries in the world $=$ the sum of the countries in each of the regions $=48+40+15+9+24+15+13+12+8+9=193$ countries/districts

(4) The results of Hansen test of over-identifying restrictions as shown in the Tables 5 to 6 are mostly over 0.5 . This indicates that the orthogonality conditions cannot be rejected at 5\% level or even at $1 \%$ level, and the instruments used are not correlated with the residuals. Moreover, the first order autocorrelation (AR1) in the tables are at the p-value larger than 0.05 , which indicate that the null hypothesis of the serial correlation test in the errors in the first-difference regression exhibits no second-order serial correlation. Therefore, our analysis fulfils the basic requirements for GMM estimation. 
(Group B)

Table 7: System GMM regression of levels of FDI Inflows as percentage of real GDP to countries by regions classified by Legal Origins theory

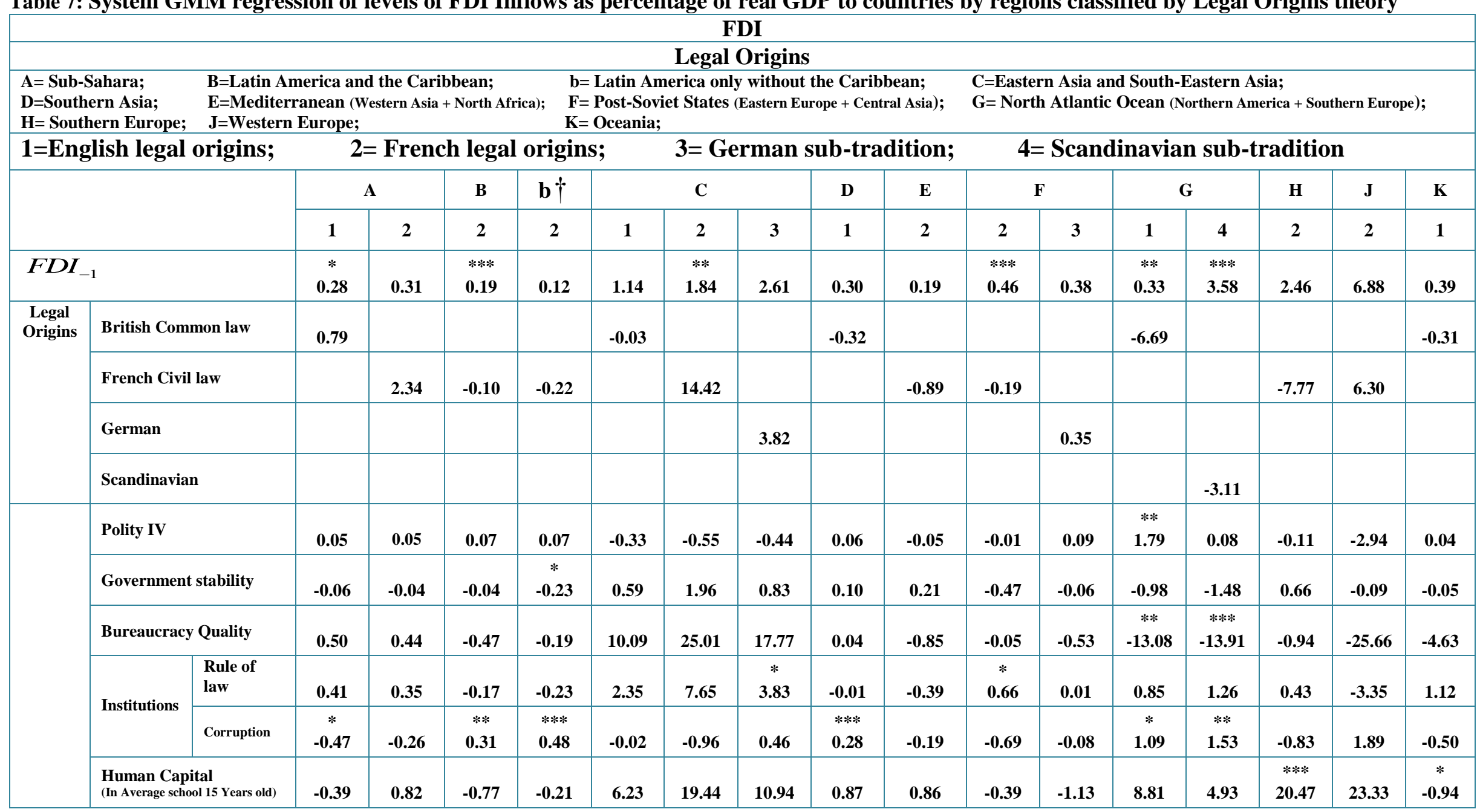




\begin{tabular}{|c|c|c|c|c|c|c|c|c|c|c|c|c|c|c|c|c|}
\hline $\begin{array}{l}\text { Infrastructure } \\
\text { (Fixed Tel line) }\end{array}$ & 0.39 & 0.34 & 0.09 & 0.25 & -0.07 & $\begin{array}{c}* \\
7.26\end{array}$ & 0.59 & 0.01 & 0.17 & 0.19 & 0.12 & $\begin{array}{c}* \\
7.84\end{array}$ & $\begin{array}{c}* * \\
4.05\end{array}$ & $\begin{array}{c}* * \\
1.22\end{array}$ & -18.26 & 0.23 \\
\hline Trade Openness & 1.05 & 0.34 & 0.18 & 0.23 & 3.72 & 9.51 & 6.44 & -0.30 & 2.05 & 0.48 & -0.08 & 0.85 & $\begin{array}{c}* * \\
6.27\end{array}$ & 2.05 & -51.66 & -1.27 \\
\hline $\begin{array}{l}\text { Wealth (GDP per } \\
\text { capita) }\end{array}$ & 1.28 & -0.32 & -0.23 & $\begin{array}{c}* \\
-0.96\end{array}$ & 3.82 & 13.08 & 4.76 & $\begin{array}{c}* * \\
-0.65\end{array}$ & 0.86 & 0.14 & 0.68 & -6.05 & $\begin{array}{c}* * * \\
10.02\end{array}$ & -0.13 & 52.01 & 1.67 \\
\hline M2/GDP & -1.16 & -1.58 & 0.00 & -0.06 & -5.29 & -21.92 & -9.43 & $\begin{array}{c}* \\
0.62\end{array}$ & -0.75 & -0.26 & 0.68 & $\begin{array}{c}* \\
9.53\end{array}$ & $\begin{array}{c}* * \\
-6.83\end{array}$ & -6.47 & -31.98 & $\mathbf{0 . 3 7}$ \\
\hline Inflation & 0.27 & 0.25 & 0.03 & 0.01 & -0.26 & $\begin{array}{c}* \\
0.52\end{array}$ & -0.16 & $\begin{array}{c}* \\
0.54\end{array}$ & -0.13 & -0.00 & 0.19 & 0.88 & $\begin{array}{l}* * * * \\
0.90\end{array}$ & 0.18 & -2.44 & -0.12 \\
\hline Number of Instruments & 19 & 20 & 20 & 20 & 19 & 19 & 19 & 17 & 20 & 19 & 19 & 20 & 19 & 20 & 19 & 19 \\
\hline $\begin{array}{l}\text { Number of Country }{ }^{\Delta} \\
\text { (Total: 193) }\end{array}$ & \multicolumn{2}{|c|}{48} & \multicolumn{2}{|c|}{40} & \multicolumn{3}{|c|}{15} & 9 & 24 & \multicolumn{2}{|c|}{15} & \multicolumn{2}{|c|}{13} & 12 & 8 & 9 \\
\hline Observations & 50 & 50 & 90 & 72 & 44 & 44 & 44 & 50 & 58 & 50 & 50 & 44 & 44 & 45 & 55 & 41 \\
\hline AR1 (p-value) & 0.789 & 0.681 & 0.996 & 0.819 & 0.878 & 0.727 & 0.320 & 0.889 & 0.669 & 0.808 & 0.892 & 0.792 & 0.766 & 0.725 & 0.997 & 0.875 \\
\hline Wald statistic & $\mathbf{0}$ & $\mathbf{0}$ & $\mathbf{0}$ & $\mathbf{0}$ & $\mathbf{0}$ & $\mathbf{0}$ & $\mathbf{0}$ & $\mathbf{0}$ & $\mathbf{0}$ & $\mathbf{0}$ & $\mathbf{0}$ & $\mathbf{0}$ & $\mathbf{0}$ & $\mathbf{0}$ & $\mathbf{0}$ & $\mathbf{0}$ \\
\hline Hansen p-value & 0.870 & 0.970 & 0.923 & 0.913 & 0.764 & 0.746 & 0.875 & 1.000 & 0.842 & 0.904 & 1.000 & 0.913 & 0.672 & 0.948 & 1.000 & 1.000 \\
\hline $\begin{array}{l}\text { GMM instruments for levels: } \\
\text { difference (null H = exogenous) }\end{array}$ & 1.000 & 1.000 & 1.000 & 1.000 & 0.937 & 0.942 & 1.000 & 1.000 & 0.229 & 0.602 & 1.000 & 0.863 & 0.880 & 0.232 & 1.000 & 1.000 \\
\hline $\begin{array}{l}\text { GMM ((ln corruption index, } \\
\text { lag(1)) }\end{array}$ & 1.000 & 1.000 & 1.000 & 1.000 & 0.699 & 0.688 & 1.000 & 1.000 & 0.753 & 0.990 & 1.000 & 0.954 & 0.779 & 0.718 & 1.000 & 1.000 \\
\hline $\begin{array}{l}\text { Hansen test excluding group: } \\
\text { Difference (null } \mathbf{H}=\text { exogenous) }\end{array}$ & 1.000 & 1.000 & 1.000 & 1.000 & 0.717 & 0.709 & 1.000 & 1.000 & 0.867 & 0.999 & 1.000 & 0.878 & 0.902 & 0.929 & 1.000 & 1.000 \\
\hline Legal families & 1 & 2 & 2 & 2 & 1 & 2 & 3 & 1 & 2 & 2 & 3 & 1 & 4 & 2 & 2 & 1 \\
\hline Regions/districts & & & & & & C & & D & $\mathbf{E}$ & & & & & $\mathbf{H}$ & $\mathbf{J}$ & $\mathbf{K}$ \\
\hline
\end{tabular}

Note: (1) Confidence level: $* * *, * *$, and $*$ indicate that the coefficient is significantly different from zero at the $1 \%, 5 \%$ and $10 \%$ respectively

(2) $\uparrow$ We specifically put the countries of Central America and South America in group (b), which exclude the island countries in the Caribbean in order to assess the FDI activities solely in those larger countries in the continents

(3) The corresponding figures taken to support our analytic results are underlined for easier reference

(4) ${ }^{\Delta}$ The total number of countries in the world $=$ the sum of the countries in each of the regions $=48+40+15+9+24+15+13+12+8+9=193$ countries/districts 
(Group B)

Table 8: System GMM regression of levels of FDI Inflows as percentage of real GDP to countries by regions classified by colonial Powers FDI

\section{Colonial Powers}

\begin{tabular}{|c|c|c|c|c|c|c|c|c|c|c|c|c|c|c|c|c|c|c|c|c|c|c|}
\hline \multicolumn{7}{|c|}{$\begin{array}{l}\text { A= Sub-Sahara; } \quad \text { B=Latin America and the Caribbean; } \\
\text { F= Post-Soviet States (Eastern Europe +Central Asia); } \\
\text { J= Western Europe; K= Oceania }\end{array}$} & \multicolumn{8}{|c|}{$\begin{array}{l}\text { C=Eastern Asia and South-Eastern Asia; D=Southern Asia; } \\
\text { G= North Atlantic Ocean ( Northern America and Northern Europe); }\end{array}$} & \multicolumn{7}{|c|}{$\begin{array}{l}\text { E=Mediterranean (western Asia +North Africa); } \\
\text { H=Southern Europe; }\end{array}$} & \\
\hline \multirow{3}{*}{\multicolumn{2}{|c|}{$\begin{array}{ll}\text { 1= Former English; } & 2= \\
\text { 8= Ottoman Colony; } & 9=\end{array}$}} & rmes & $\begin{array}{l}\text { rench } \\
\text { olony }\end{array}$ & $\begin{array}{r}3=\mathrm{Sp} \\
\text { xcludi }\end{array}$ & $\begin{array}{l}\text { aish C } \\
\text { g the } \mathrm{C}\end{array}$ & $\begin{array}{l}\text { lony; } \\
\text { aribbe }\end{array}$ & \multirow{2}{*}{\multicolumn{4}{|c|}{$\begin{array}{c}\begin{array}{c}\text { 4=Portuguese Colony; } \\
\text { 10=Dutch colony; }\end{array} \\
\text { B }\end{array}$}} & $\begin{array}{l}5=\text { Gern } \\
11=\text { mix }\end{array}$ & $\begin{array}{ll}\text { an nev } \\
\text { a legal }\end{array}$ & $\begin{array}{l}\text { r colo } \\
\text { rigin }\end{array}$ & & \multicolumn{3}{|c|}{$\begin{array}{l}\text { 6=Japanese Colony; } \\
12=\text { others }\end{array}$} & \multicolumn{5}{|c|}{$7=$ Austro-Hungarian } \\
\hline & & \multicolumn{4}{|c|}{$\mathbf{A}$} & B & & & & & \multicolumn{4}{|c|}{$\mathbf{C}$} & D & $\mathbf{E}$ & \multicolumn{2}{|c|}{$\mathbf{F}$} & \multirow{2}{*}{$\begin{array}{l}\mathbf{G} \\
1\end{array}$} & \multirow{2}{*}{\begin{tabular}{c|}
$\mathbf{H}$ \\
2
\end{tabular}} & \multirow{2}{*}{$\begin{array}{l}\mathbf{J} \\
2\end{array}$} & \multirow{2}{*}{$\begin{array}{c}\mathbf{K} \\
1\end{array}$} \\
\hline & & 11 & 4 & 2 & 1 & 1 & 3 & 4 & 9 & 10 & 5 & 1 & 6 & 12 & 1 & 8 & 7 & 12 & & & & \\
\hline \multicolumn{2}{|c|}{$F D I_{-1}$} & *.33 & 0.18 & $\begin{array}{c}* * * \\
0.30\end{array}$ & $\begin{array}{l}* * * * \\
\mathbf{0 . 3 5}\end{array}$ & 0.42 & $\begin{array}{ll}* * * * \\
0.03\end{array}$ & 0.04 & 0.06 & $\begin{array}{c}* \\
0.21\end{array}$ & 0.84 & 0.47 & 0.84 & $\begin{array}{l}* * * * \\
0.87\end{array}$ & 0.04 & 0.02 & $\mathbf{0 . 3 0}$ & 0.15 & 1.55 & $\mathbf{0 . 3 2}$ & 11.12 & 0.39 \\
\hline & Former English & & & & 1.29 & -2.29 & & & & & & $\begin{array}{r}* * * * \\
\underline{-6.17} \\
\end{array}$ & & & -2.49 & & & & 11.25 & & & -0.03 \\
\hline & Former French & & & -1.15 & & & & & & & & & & & & & & & & 3.99 & -113.09 & \\
\hline & Spanish colony & & & & & & $\begin{array}{l}* * * * \\
\underline{2.06} \\
\end{array}$ & & & & & & & & & & & & & & & \\
\hline & Portuguese colony & & 1.04 & & & & & 1.69 & & & & & & & & & & & & & & \\
\hline & $\begin{array}{l}\text { German never } \\
\text { Colonised }\end{array}$ & & & & & & & & & & $\begin{array}{c}* * * \\
-\underline{-26.70}\end{array}$ & & & & & & & & & & & \\
\hline & $\begin{array}{l}\text { Austro- } \\
\text { Hungarian }\end{array}$ & & & & & & & & & & & & & & & & 2.27 & & & & & \\
\hline & Ottoman colony & & & & & & & & & & & & & & & 2.09 & & & & & & \\
\hline & $\begin{array}{l}\text { Spanish colony } \\
\text { excluding the } \\
\text { Caribbean }\end{array}$ & & & & & & & & $\begin{array}{c}* * * \\
\mathbf{5 . 6 2} \\
\end{array}$ & & & & & & & & & & & & & \\
\hline & Dutch colony & & & & & & & & & -3.77 & & & & & & & & & & & & \\
\hline & Mixed legal origin & 2.22 & & & & & & & & & & & & & & & & & & & & \\
\hline & Others & & & & & & & & & & & & & $\begin{array}{c}* * \\
19.12 \\
\end{array}$ & & & & $\begin{array}{c}* * \\
\mathbf{1 . 4 0} \\
\end{array}$ & & & & \\
\hline \multirow[t]{3}{*}{$X_{i t}$} & Polity IV & 0.02 & 0.04 & 0.05 & 0.02 & 0.06 & 0.00 & 0.08 & -0.03 & 0.06 & -0.03 & $\begin{array}{c}* \\
-0.23\end{array}$ & -0.03 & $\begin{array}{c}* * \\
-\mathbf{0 . 1 1}\end{array}$ & -0.02 & 0.01 & 0.02 & 0.02 & -1.66 & 0.24 & -3.97 & 0.04 \\
\hline & $\begin{array}{l}\text { Bureaucracy } \\
\text { Quality }\end{array}$ & 0.34 & 0.17 & 0.52 & 0.39 & -0.16 & 0.16 & -0.40 & 0.56 & -0.32 & -0.51 & 5.10 & -0.51 & 0.47 & -0.02 & -1.29 & 0.21 & -0.17 & -5.65 & -2.11 & -15.93 & -4.63 \\
\hline & $\begin{array}{l}\text { Government } \\
\text { Stability }\end{array}$ & -0.09 & -0.09 & -0.05 & -0.09 & -0.07 & -0.04 & -0.03 & -0.06 & -0.05 & -0.17 & 0.19 & -0.17 & 0.02 & $\begin{array}{c}* \\
-0.23\end{array}$ & 0.18 & -0.03 & 0.00 & $\begin{array}{c}* * \\
-0.66\end{array}$ & 0.29 & -0.80 & $\begin{array}{c}* * \\
-0.05\end{array}$ \\
\hline
\end{tabular}




\begin{tabular}{|c|c|c|c|c|c|c|c|c|c|c|c|c|c|c|c|c|c|c|c|c|c|c|}
\hline \multirow{2}{*}{$\begin{array}{l}\text { Instituti } \\
\text { ons }\end{array}$} & $\begin{array}{l}\text { rule of } \\
\text { law }\end{array}$ & $\stackrel{*}{*}$ & 0.34 & 0.41 & 0.79 & -0.11 & -0.02 & -0.10 & -0.01 & -0.09 & 0.28 & $\stackrel{*}{*}$ & 0.28 & $\begin{array}{l}* * * * \\
0.73\end{array}$ & -0.41 & 0.02 & 0.04 & 0.07 & 1.12 & $\stackrel{*}{*}$ & -0.40 & 1.120 \\
\hline & $\begin{array}{l}\text { Corrupti } \\
\text { on }\end{array}$ & $\begin{array}{c}* * \\
-0.62\end{array}$ & -0.50 & $\begin{array}{c}* * \\
-0.46 \\
\end{array}$ & $\begin{array}{c}* \\
-0.63\end{array}$ & $\begin{array}{l}* * * \\
0.20\end{array}$ & $\begin{array}{c}* * \\
0.23\end{array}$ & 0.35 & $\begin{array}{c}* * \\
0.36\end{array}$ & $\begin{array}{c}* * \\
0.28\end{array}$ & -0.15 & -0.52 & -0.15 & $\begin{array}{c}* * * \\
-\mathbf{0 . 8 3}\end{array}$ & -0.43 & -0.08 & -0.09 & -0.07 & 1.75 & -0.65 & -0.47 & -0.50 \\
\hline \multicolumn{2}{|c|}{\begin{tabular}{|l|} 
Human Capital \\
Average Secondary \\
School 15 \\
\end{tabular}} & -1.24 & 0.44 & -0.41 & -1.50 & -0.93 & $\mathbf{0 . 4 0}$ & -0.46 & -0.44 & -0.56 & 0.31 & $\begin{array}{c}* \\
4.27 \\
\end{array}$ & 0.31 & 2.28 & -6.79 & 0.41 & -0.35 & -0.23 & 8.90 & $\begin{array}{c}* * \\
21.76 \\
\end{array}$ & 31.07 & $\begin{array}{c}* \\
-0.94 \\
\end{array}$ \\
\hline \multicolumn{2}{|c|}{$\begin{array}{l}\text { Infrastructure } \\
\text { (Fixed Tel line) }\end{array}$} & 0.42 & 0.30 & $\mathbf{0 . 4 3}$ & 0.44 & -0.17 & 0.12 & 0.09 & 0.29 & 0.11 & 0.48 & $-\mathbf{- 0 . 3 8}$ & 0.48 & 0.46 & $\begin{array}{c}* \\
0.99 \\
\end{array}$ & -0.26 & 0.10 & 0.01 & $\begin{array}{c}* \\
8.49 \\
\end{array}$ & $\begin{array}{c}* * \\
1.53 \\
\end{array}$ & -22.51 & $\mathbf{0 . 2 3}$ \\
\hline \multicolumn{2}{|c|}{ Trade Openness } & 0.73 & -0.53 & 1.38 & 0.88 & 0.34 & 0.35 & 0.25 & 0.43 & 0.12 & -0.49 & 2.43 & -0.49 & 2.10 & $\begin{array}{c}* \\
1.48\end{array}$ & 2.88 & 0.04 & 0.93 & 5.31 & 3.49 & $\begin{array}{c}* \\
-75.67\end{array}$ & -1.27 \\
\hline \multicolumn{2}{|c|}{$\begin{array}{l}\text { Wealth (GDP } \\
\text { per capita) }\end{array}$} & 0.64 & 0.90 & 1.72 & 0.99 & 0.04 & 0.07 & -0.35 & 0.29 & -0.27 & -0.73 & 0.10 & -0.73 & 1.87 & -0.06 & 1.17 & -0.05 & 0.19 & -2.17 & -1.47 & $\begin{array}{c}* \\
64.19\end{array}$ & 1.67 \\
\hline \multicolumn{2}{|c|}{ M2/GDP } & 1.44 & -0.93 & -1.47 & 1.30 & -0.04 & -0.03 & -0.03 & -0.29 & -0.09 & 0.30 & -0.97 & 0.30 & $\begin{array}{c}* \\
-3.96\end{array}$ & 1.15 & -1.11 & -0.11 & -0.37 & -3.20 & -6.60 & $\begin{array}{c}* \\
-34.56\end{array}$ & $\mathbf{0 . 3 7}$ \\
\hline \multicolumn{2}{|c|}{ Inflation } & 0.27 & 0.22 & 0.33 & 0.30 & 0.01 & -0.01 & -0.04 & -0.02 & 0.01 & 0.32 & -0.08 & 0.32 & 0.08 & -0.13 & -0.11 & 0.04 & -0.03 & 0.07 & 0.43 & -0.82 & -0.12 \\
\hline \multicolumn{2}{|c|}{ Number of Instruments } & 19 & 19 & 19 & 19 & 19 & 19 & 19 & 19 & 19 & 19 & 19 & 19 & 19 & 19 & 19 & 19 & 19 & 19 & 19 & 19 & 19 \\
\hline \multicolumn{2}{|c|}{$\begin{array}{l}\text { Number of Country }{ }^{\Delta} \\
\text { (Total: 193) }\end{array}$} & \multicolumn{4}{|c|}{48} & \multicolumn{5}{|c|}{40} & \multicolumn{4}{|c|}{15} & 9 & 24 & \multicolumn{2}{|c|}{15} & 13 & 12 & 8 & 9 \\
\hline \multicolumn{2}{|l|}{ Observations } & 50 & 50 & 50 & 50 & 90 & 90 & 90 & 72 & 90 & 44 & 44 & 44 & 50 & 50 & 64 & 50 & 50 & 42 & 45 & 45 & 41 \\
\hline \multicolumn{2}{|l|}{ AR1 (p-value) } & 0.910 & 0.922 & 0.899 & 0.932 & 0.956 & 0.787 & 0.698 & 0.501 & 0.964 & 0.429 & 0.410 & 0.859 & 0.789 & 0.405 & 0.564 & 0.434 & 0.886 & 0.724 & 0.968 & 0.902 & 0.799 \\
\hline \multicolumn{2}{|l|}{ Wald statistics } & $\mathbf{0}$ & $\mathbf{0}$ & $\mathbf{0}$ & $\mathbf{0}$ & $\mathbf{0}$ & $\mathbf{0}$ & $\mathbf{0}$ & $\mathbf{0}$ & $\mathbf{0}$ & $\mathbf{0}$ & $\mathbf{0}$ & $\mathbf{0}$ & $\mathbf{0}$ & $\mathbf{0}$ & $\mathbf{0}$ & $\mathbf{0}$ & $\mathbf{0}$ & $\mathbf{0}$ & $\mathbf{0}$ & $\mathbf{0}$ & $\mathbf{0}$ \\
\hline \multicolumn{2}{|l|}{ Hansen p-value } & 0.890 & 0.904 & 0.879 & 0.992 & 0.927 & 0.923 & 0.966 & 0.947 & 0.420 & 0.600 & 0.562 & 1.000 & 0.922 & 0.601 & 0.982 & 0.745 & 0.890 & 0.962 & 1.000 & 0.990 & 0.896 \\
\hline \multicolumn{2}{|c|}{$\begin{array}{l}\text { GMM instruments for } \\
\text { levels:difference (null } \mathrm{H}= \\
\text { exogenous) }\end{array}$} & 1.000 & 1.000 & 1.000 & 1.000 & 1.000 & 1.000 & 1.000 & 1.000 & 1.000 & 1.000 & 1.000 & 1.000 & 1.000 & 1.000 & 1.000 & 1.000 & 1.000 & 1.000 & 1.000 & 1.000 & 1.000 \\
\hline \multicolumn{2}{|c|}{$\begin{array}{l}\text { GMM ((In_corruption_index, } \\
\text { lag(1)) }\end{array}$} & 1.000 & 1.000 & 1.000 & 1.000 & 1.000 & 1.000 & 1.000 & 1.000 & 1.000 & 1.000 & 1.000 & 1.000 & 1.000 & 1.000 & 1.000 & 1.000 & 1.000 & 1.000 & 1.000 & 1.000 & 1.000 \\
\hline \multicolumn{2}{|c|}{$\begin{array}{l}\text { Hansen test excluding group: } \\
\text { Difference (null } \mathrm{H}=\text { exogenous) }\end{array}$} & 1.000 & 1.000 & 1.000 & 1.000 & 1.000 & 1.000 & 1.000 & 1.000 & 1.000 & 1.000 & 1.000 & 1.000 & 1.000 & 1.000 & 1.000 & 1.000 & 1.000 & 1.000 & 1.000 & 1.000 & 1.000 \\
\hline \multicolumn{2}{|l|}{ Legal families } & 11 & 4 & 2 & 1 & 1 & 3 & 4 & 9 & 10 & 5 & 1 & 6 & 12 & 1 & 8 & 7 & 12 & 1 & 2 & 2 & 1 \\
\hline \multicolumn{2}{|c|}{ Regions/districts } & \multicolumn{4}{|c|}{$\mathbf{A}$} & \multicolumn{5}{|c|}{ B } & \multicolumn{4}{|c|}{ C } & D & $\mathbf{E}$ & \multicolumn{2}{|c|}{$\mathrm{F}$} & G & $\mathbf{H}$ & $\mathbf{J}$ & $\mathbf{K}$ \\
\hline
\end{tabular}

Note: (1) Confidence level: $* * *, * *$, and $*$ indicate that the coefficient is significantly different from zero at the $1 \%, 5 \%$ and $10 \%$ respectively

(2) The corresponding figures taken to support our analytic results are underlined for easier reference

(3) ${ }^{\Delta}$ The total number of countries in the world $=$ the sum of the countries in each of the regions $=48+40+15+9+24+15+13+12+8+9=193$ countries/districts 
